\title{
A SOCIEDADE CASTREXA A TRAVÉS DA EPIGRAFÍA
}

\author{
ROSA BRAÑAS ABAD
}

\section{Resume}

Ofrécese unha mirada ás diferentes interpretacións sobre o significado oculto do signo epigráfico en forma de «C invertido» referido ás comunidades da Gallaecia antiga. Partindo de diversas hipóteses sociolóxicas e históricas, estas son as diferentes lecturas do signo propostas ata hoxe dende o comezo do seu estudio: Centuria, Gens/Gentilitas, Census, Castellum/Castrum, Conventus... e novamente Centuria.

\section{Palabras Clave}

Gallaecia, Castrexo, Centuria, Census, Castellum, Gens, Gentilitas.

\begin{abstract}
«The Society of the Castro-Culture through the Epigraphy». We have a look at the different interpretations on the hidden meaning of the epigraphic sign similar to an «inverted C» referred to the ancient Gallaecia communities. Assuming diverse sociological and historical hypotheses, these are the different readings of the sign suggested until now: Centuria, Gens/ Gentilitas, Census, Castellum/Castrum, Conventus... and again Centuria.
\end{abstract}

\section{Key Words}

Gallaecia, Castro-Culture, Centuria, Census, Castellum, Gens, Gentilitas. 
A sociedade castrexa do noroeste entra na Historia Antiga coas primeiras noticias sobre as campañas de Cepión e de Bruto levadas contra os brácaros en torno ós anos 139 e 138 a.C. (Apiano Iber. 70, 73-74) Poucas máis referencias hai nas fontes clásicas a estas poboacións en tempos prerromanos, pois a parte doutra breve noticia sobre a expedición de César ata as costas de Brigantium polo ano 61 a.C. (Dion Casio 37, 52-3) ninguén máis que Estrabón proporciona a penas informes de consideración sobre aquelas xentes que nos remonten a unha etapa anterior á conquista romana ${ }^{1}$.

Debido á escaseza xeral de información escrita transmitida polos autores grecolatinos, boa parte do labor de investigación dos historiadores da Antigüidade relativa a esta sociedade centrouse no estudio das fontes epigráficas. O que parecía percibirse a través desta clase de documentos é que, dende que rematan as Guerras Cántabras ata a concesión do estatuto de latinidade polo ano 70 d.C., as comunidades indíxenas estaban a atravesar un período de vagarosa adaptación ó modo de organización romana, durante o cal, sen embargo, non estaba de todo claro cómo ou por qué medios se gobernaban as poboacións castrexas. Os resultados das investigacións neste terreo apuntaban a que as institucións nativas foron as responsables de dirixir o proceso de adaptación ó modelo político romano, o que implicaba, paralelamente, que durante este tempo debían xestionar a vida das comunidades en virtude dos seus propios principios de goberno e mecanismos administrativos.

A reconstrucción deste proceso por parte dos historiadores xirou practicamente de modo exclusivo en torno ó enigmático signo en forma de C invertido $(\supset$ ) que acompaña nos documentos epigráficos do noroeste a algúns topónimos castrexos ${ }^{2}$. O primeiro en intentar dar unha solución ó interrogante que o signo presentaba foi A. Schulten (1943), a partir de quen se admitiu durante longo tempo a traducción do $\supset$ por centuria, ata que $\mathrm{M}^{\mathrm{a}} \mathrm{L}$. Albertos propuxo no ano 1975 a lectura castellum (Albertos, Ma L., 1975: 63-6).

Entre as máis de tres décadas que separan ambas propostas, a maioría dos especialistas mantería a equivalencia do $\supset$ e centuria, aínda que introducindo matices e correccións á interpretación inicial. Finalmente, ó tempo que a hipótese de A. Schulten sería definitivamente abandonada e a de $\mathrm{M}^{\mathrm{a}} \mathrm{L}$. Albertos acabaría atraendo á maioría dos historiadores, produciríase un aliñamento dos especialistas en torno a dúas correntes de interpretación baseadas en modelos analíticos opostos: un

\footnotetext{
${ }^{1}$ Sobre as expedicións militares por terras galaicas en época republicana ver Martínez Mera 2001.

${ }^{2}$ Recóllense no apéndice epigráfico I. as inscricións que rexistran a presencia deste signo.
} 
modelo xentilicio, que sostiña que as comunidades galaicas se artellaban, como no resto da Hispania indoeuropea, en unidades sociais básicas de carácter familiar; e un modelo político-territorial segundo o cal o único factor de cohesión interna na sociedade galaica era o principio de comunidade local representada polo castro, o que excluiría calquera modo de organización fundada no parentesco e aproximaría a aldea castrexa á constitución da civitas romana.

Aínda que entre as dúas hipóteses enfrontadas no estudio do signo epigráfico se dera certa variedade de interpretacións e non as poidamos reducir exclusivamente a dúas, entre os apartados 1 e 3 expoñeranse as distintas contribucións segundo se adscriban á defensa da solución «xentilicia» ou «político-territorial», pois, ata a década dos 90 da pasada centuria, a penas se nos ofrecía outra alternativa ó respecto. Soamente ó final, no apartado 4, veremos unha interpretación novidosa do problema, aínda que só se nos presente por agora en proceso de maduración. Entre a formulación de Schulten e as achegas máis recentes ó tema, veremos tamén cómo se desenvolveu un duro debate entre algúns historiadores acerca dos problemas epigráficos que rodean ó signo $\supset$.

\section{A CENTURIA GALAICA}

As poboacións dos catro conventos setentrionais da Tarraconense mostraban na Antigüidade, segundo Schulten, un forte predominio das organizacións xentilicias, o tipo de comunidades que nos dan a coñecer as fontes baixo a denominación de gentes en case toda a provincia, agás no sector galaico, onde se coñecían como centurias $(\supset)$. O signo representaría, daquela, ós clans célticos do noroeste, definidos polo noso autor como as entidades políticas máis pequenas, compostas por un grupo de familias descendentes dun matrimonio e con capacidade autárquica no plano político e económico ${ }^{3}$. Esta institución social corresponderíase tamén coa fratría grega, a gens romana, e os seus supostos paralelos bárbaros: as cognationes e os grupos de propinqui mencionados por César e Tácito entre os xermanos, e a syngéneia, da que tamén se fala en relación coas formas organizativas características das sociedades antigas máis primitivas. De acordo con Schulten, en definitiva, o clan tería existido entre todos os pobos antigos e baixo calquera destas denominacións.

\footnotetext{
${ }^{3} \mathrm{O}$ clan bárbaro caracterizaríase por ser un Estado en canto entidade independente, opoñéndose á fratría e máis á gens clásicas por teren perdido a autonomía a partir da súa absorción por parte da Cidade (1962: 69).
} 
O clan céltico en España, di, chámase gentilitas, gens, centuria, cognatio de centuria, familia. (1962: 69-70) Mais, se nalgún momento propón distinguir diferencias de nivel organizativo entre alomenos dúas desas entidades, identificando a gens e a gentilitas coa tribo e o clan respectivamente, volve a complicar as relacións establecidas afirmando que como tamén a tribo se compoñia de familias, algunhas veces ó clan chámaselle gens (1962: 71-24).

A interpretación do signo proposta polo autor alemán baseouse nunha inscrición procedente de Aldeia Nova (Bragança) na que se menciona unha cognatio supostamente asociada a unha centuria: Aemilio Balaeso signifero alae Sabininae Cognatio de Cen[turia?] (CIL II Sup., $1174=E E$ VIII 1285). Esta mención, unida ó feito de que nas fontes aparecen referidos para outras sociedades antigas grupos que significan o mesmo, «grupo de cen» (huntari entre os alamanes, hundred entre os anglosaxóns, centena nos francos romanizados), permitiu inferir para o clan galaico o mesmo número de membros, o que xustificaría, ó cabo, que recibise a denominación latina que expresaba para unha agrupación social a mesma composición numérica: centuria (a unidade militar romana de cen soldados; cf. 1962: 73-74).

A partir deste momento quedaba establecido o significado do signo como centuria, unidade básica na organización política das comunidades hispanas que conservaban en época romana o seu carácter tribal.

Máis tarde F. Rodríguez Adrados, afondando no estudio comparativo das institucións xentilicias comúns ós indoeuropeos occidentais, propuxo explicar a composición interna dos sub-grupos compoñentes da tribo a partir do significado etimolóxico das súas denominacións. Segundo este autor, existiría cristalizado entre os indoeuropeos occidentais un esquema invariable determinado pola combinación en base decimal de todos os grupos ata conformaren a unidade superior ou tribo (Rodríguez Adrados, 1948: 5-10). Pero, a diferencia de Schulten, Adrados non consideraba a centuria como grupo de 100 persoas, senón de 100 gentes, o que deducía a partir da comparanza con outras sociedades indoeuropeas afíns: en Roma a centuria correspondíase coa unidade de distribución territorial da tribo, que repartía en 100 heredia os lotes de terra asignados a cada unha das 10 gentes que formaban ó tempo as 10 curias compoñentes da tribo ${ }^{6}$. Os pobos xermánicos

\footnotetext{
${ }^{4}$ Pode verse unha crítica das impropiedades terminolóxicas comúns nesta obra de Schulten no artigo de J.C. Bermejo (1978-80: 96 ss.) que se analizará máis adiante.

${ }^{5}$ Atopaba para esta inscrición un paralelo en Dalmacia: M(atri) M(agnae) Cognatio de suo ampliavit.

${ }^{6}$ Os 10 senadores por curia que formaban a decuria, virían poñer de manifesto, novamente, a composición decimal desta, posto que a cada curia lle corresponderían 10 gentes (1948: 11-41)
} 
constituíanse en huntari e hundred «grupos de 100 », termos que designaban divisións territoriais identificadas igualmente coas tribos que as ocupaban. No mundo celta atopábase a túath, que se compoñía en Gales de cantref «100 casas» e en Irlanda de tricha «trinta centos», con 30 bailes cada unha, etc (1948: 10724, 135).

Adrados dubidaba de que o valor xentilicio desta institución pervivise no mundo galaico en época romana, mais do que si estaba certo era da orixe celta da propia denominación de centuria, termo que traduciría directamente a expresión "grupo de cento» ${ }^{7}$, e a partir da cal se distribuirían en orde decrecente as gentescognationes que a compoñían: na Hispania céltica existe unha unidade chamada cognatio que é inferior á centuria. A cognatio non pode ser máis que a gens, entendida aquí como "gran familia» (todo o cal habería que relacionar coas gentes e cognationes mencionadas por César respecto dos xermanos ( $B G$ VI 22; VII 32; cf. Adrados, 1948: 130, 135).

Se ben a hipótese de Adrados sobre a composición numérica destas unidades organizativas indíxenas non tivo nin podía ter continuidade ou proveito para posteriores estudios, non se pode igualmente xustificar que ninguén despois del efectuase un esforzo semellante, alomenos no terreo estrictamente sociolóxico, por establecer posibles afinidades entre os indoeuropeos extra-peninsulares mailos hispanos ${ }^{8}$. Polo demais, parece acertado considerar con el que a definición territorial destes grupos pode comprenderse en función de necesidades políticas, fiscais e militares, sen necesidade de negarmos o seu carácter xentilicio, co que en absoluto podemos considerar incompatible se por «xentilicio» entendemos o sistema social que ten como principal factor de cohesión as relacións de parentesco9.

Unha das primeiras críticas dirixidas a estas investigacións, feita con afán revisionista, pero bastante parca en conclusións, foi a levada a cabo por Caro Baroja

\footnotetext{
${ }^{7}$ Entre os celtas do noroeste a unidade politico-social é a centuria, mandada por un xefe hereditario ou escollido alomenos na mesma familia. Ás veces recibe a denominación de gens ou gentilitas; o nome centuria é a traducción da palabra celta que significaría "grupo de cento»e designaria un conxunto de 100 gentes (1948: 137).

${ }^{8}$ Agás no referente á distribución xeográfica dos pobos indoeuropeos consecutivamente asentados na Península e a xeneralización da denominación gentilitas indistintamente para todos os clans ou sub-fraccións desta orixe (entendidos como unidades subordinadas ás gentes ou tribos), A.Tovar (1949: 96-118) non engadiu nada substancial á interpretación histórica das centurias con respecto ós seus predecesores.

${ }^{9}$ Referíndose a Iguvium, di que a cuestión dos nomes non é decisiva para probar ou rexeitar o primitivo carácter xentilicio das organizacións (1948: 83) argumento que, como veremos, tantas veces foi esgrimido en contra da proposta xentilicia para os «grupos con $\supset$ ».
} 
$\left(1977 \mathrm{a}^{10}\right)$ sobre a xeral falta de precisión terminolóxica no tratamento das institucións sociais do norte peninsular. Comezaba este autor destacando a impropiedade en que incorrían os historiadores ó falaren aquí de «tribos», atribuíndo o seu uso indiscriminado a unha actitude cómoda que pretendese, baixo un termo xenérico, agachar o descoñecemento da realidade deses pobos (1977a: 32-33, preferindo botar man dos termos grego e latino genos e gens, opción igualmente arbitraria tendo en conta que se trata de realidades alleas ás institucións indíxenas ibéricas).

Pola súa parte, intentaría esclarecer as relacións entre as diferentes categorías políticas documentadas nas fontes, nas que, ó cabo, non se presenta máis que unha patente confusión terminolóxica. Pero o traballo de J. Caro Baroja, lonxe de dar un enfoque ou solución sociolóxica ó tema, remataría por convertelo nun problema basicamente epigráfico: cando os Cántabros e os Ástures mesmos, no s. I ou II d.C. aceptaban a súa reducción ou equiparación a gentes non podía ser puro capricho (1977a: 33). A proba de que o grupo superior, ou de $1^{\mathrm{a}}$ orde nas súas categorías, se corresponde coa noción de gens, manifestaríase en varias inscricións nas que Cántabros, Ástures, etc. se acompañan desta denominación (cf. CIL II 4192; tamén CIL II 4233; 4192; ademais os autores latinos chaman "gens» e non doutra forma á primeira unidade: ou se non «populus», cf. 1977a: 30). Pero a ecuación complícase ó comprobar que o propio termo gens se presenta nas fontes con evidente disparidade, como moi ben mostra a táboa de hospitalidade de Astorga (ver ó final apén. epi. II, $\mathrm{n}^{\circ} 4$ ), onde a expresión ex gente Zoelarum parece asimilable ó xenitivo de plural Orniacum, ocupando a fracción de $2^{\mathrm{a}}$ orde. Pero é que, ademais, o que na primeira parte do pacto dos Zoelas se expresa mediante o termo gentilitas, na segunda parte se relaciona con outra entidade de $3^{a}$ orde, aínda que vaia precedido de ex gente: ex gente Visaligorum ou ex gente Cabruagenigorum (1977a: 31-2).

Por outra parte, consideraba que o límite común e corrente da syngéneia (interpretada como a comunidade fóra da cal, segundo Estrabón (III 3, 7), se lapidaba ós parricidas) era o que marcaba o da «gentilitas», grupo xentilicio constituído sobre vínculos de solidariedade agnática e, no caso do noroeste, asentado posiblemente no castro; 1977a: 29 e 43). Só a alianza entre estas unidades organizativas menores desencadearía a formación de unidades superiores de $2^{\mathrm{a}}$ categoría ${ }^{11}$, como demostra a presencia de formas de integración propiamente política: o princeps e a civitas;

\footnotetext{
${ }^{10}$ Anteriormente manifestara ter dúbidas sobre a lectura de Schulten ó considerar que o $\supset$ podería significar gens (1977: 75, n. 60).

${ }^{11}$ Este autor considera os pactos de hospitalidade como mecanismos de integración política: no pacto dos Zoelas, as distintas gentilitates implicadas pactarían relacións de hospitalidade para conformaren a unidade de $2^{\mathrm{a}}$ orde (1977a: 43).
} 
outras de tipo defensivo: o oppidum; ou comercial: mercados inter-xentilicios (como os mencionados por Ptolomeo: Límico, Gigurro, Narbaso e Bíbalo). No que atinxe á unidade de $1^{a}$ categoría, sería na guerra onde a alianza entre fraccións encontraría a súa mellor expresión, posto que, para Caro Baroja, parecía ser a única circunstancia na que as unidades étnicas superiores se mostran plenamente solidarias (1977a 52).

No que se refire ó tema da centuria, coincidía con Schulten en que esta institución se correspondía coa unidade organizativa inferior, ou de $3^{\text {a }}$ categoría, pero disentía dos seus predecesores no sentido de considerar ás centurias non como grupos de descendencia unilineal, como serían as gentes, romanas ou hispanas, senón cognaticia, como se desprende da mención á cognatio de centuria na estela de Bragança. Estas cognationes, que terían en conta a descendencia por ambas liñas, patrilineal e matrilineal, relacionaríanse coas mencionadas por César a propósito dos xermanos e cos grupos de propinqui galos e xermanos tamén mencionados por César e Tácito, grupos formados en calquera caso por parentelas bilaterais ${ }^{12}$.

O problema do cognatismo das comunidades galaicas sería retomado tempo despois, aínda que non inmediatamente, senón tras reconsiderar a lectura centuria, por parte dos autores que se comentarán de seguido.

R. Étienne, G. Fabre, P. Le Roux e A. Tranoy prestarían unha atención especial ó estudio das pervivencias no noroeste hispano das estructuras sociais indíxenas en época romana, dedicándolle ó tema moitos dos traballos que contribuíron a afondar no seu coñecemento. Nun dos primeiros artigos preparados conxuntamente por Le Roux e Tranoy sobre o tema (1973), comprobábase a partir do estudio da antroponimia e teonimia indíxenas, nun número suficientemente representativo de inscricións datadas arredor de finais do século I ata o III d.C., a pervivencia en época avanzada das estructuras sociais prerromanas nos conventos brácaro e lucense, onde os procesos de urbanización e municipalización semellaban, ademais, debilmente representados.

Marcada progresivamente pola influencia romanizadora, a onomástica evolucionaría dende os usos indíxenas ata a transformación practicamente xeneralizada en modos romanos, destacando o acceso prioritario e excepcional de certos individuos a un status xurídico superior ó do resto da poboación polo exercicio de cargos administrativos ou calquera outras responsabilidades públi-

12 1977a: 44. Engade en nota (n. 246) que $a$ «Centuria» podería ser a base de aldeas no sentido máis moderno, constituidas por parentes por vías distintas. 
cas (1973: 216-7). A aceptación das modas romanizadoras preferentemente por parte destes grupos privilexiados, corresponderíase coa realidade transmitida polos datos estatísticos manexados noutro traballo no que estes mesmos autores se cuestionaban a representatividade das fontes epigráficas na reconstrucción dos procesos evolutivos que afectan ás sociedades absorbidas por Roma (cf. R. Étienne et al., 1976).

Conscientes do nesgo interpretativo que impón o estudio de tipos epigráficos reducidos, propoñían atender ás posibilidades ofrecidas por outras modalidades diferentes ás lapidarias, que son as habitualmente tratadas e as que conteñen a maioría das inscricións romanas de carácter oficial ou referidas ás elites provinciais e municipais. Tomando en consideración outros soportes materiais, como pequenos obxectos, tellas, cerámicas, etc. e escollendo como criterio para establecer os índices de romanización as porcentaxes de cognomina latinos rexistrados naqueles, observaban que a presencia de sobrenomes latinos acadaba ata o $50 \%$ en monumentos epigráficos lapidarios, mentres que os de orixe indíxena presentaban unha superioridade de ata o $75 \%$ en grafitos cerámicos (en materiais procedentes de Conimbriga, 1973: 98). Consultaban tamén a epigrafía de cara a determinar o medio ó que pertencían os individuos mencionados, distinguindo diferencias sociais e de rango a través da fórmula mediante a que se expresa a filiación. A este respecto, as combinacións entre as formas indíxenas e as romanas ofrecen un amplo abano de posibilidades, aínda que é posible precisar unha liña evolutiva concreta: dende a simple xustaposición do nome propio e o do pai en xenitivo, pasando pola expresión do $f$. ou fil. (fillo/a) tralo patronímico e a subseguinte latinización dos nomes, ata a substitución do prenome do pai polo sobrenome, etc. Agora ben, o sistema propiamente romano no que se expresan os trianomina, co patronímico abreviado e a mención da tribu, obtén unha escasa representación no conxunto dos conventos noroccidentais, referíndose case sempre a individuos vinculados ó aparato administrativo ou oficial romano, maxistrados, sacerdotes e militares, especialmente ${ }^{13}$.

Como vemos, a introducción de novas variables a ter en conta na investigación epigráfica para determinar o influxo da romanización nas distintas capas sociais, non variaba os resultados coñecidos e por estes mesmos autores dados a coñecer no primeiro artigo mencionado. $\mathrm{O}$ realmente destacable das súas pescudas era a comprobación da permanencia da onomástica e filiación indíxenas na grande maioría da poboación, do que se infería, paralelamente á conservación da relixión e cultos

\footnotetext{
${ }^{13}$ Os nomes completamente romanizados son pouco numerosos e datables, segundo estes autores, a finais do s. II ou xa no III d.C. (1973: 216).
}

Cuadernos de Estudios Gallegos, Tomo LI, Fascículo 117, Santiago 2004. (Págs. 155 - 205) 
propios tamén constatada na epigrafía ${ }^{14}$, a persistencia das estructuras sociais prerromanas trala reorganización administrativa romana. Así mesmo defendían incondicionalmente a municipalización dos conventos galaicos en época flavia, aínda que non se manifestase, como noutras áreas, na proliferación de núcleos urbanos. A xustificación da concesión do Ius Latii por parte de Vespasiano obedecería a uns simples e ben definidos intereses. Unha vez pacificada a zona tras as Guerras Cántabras, Vespasiano tería que enfrontar a reorganización destas comunidades para integralas nos cadros políticos e administrativos imperiais. Sen embargo, dende a perspectiva de que só os intereses económicos moverían os fíos da estratexia romana de conquista, o Imperio non precisaría fomentar a urbanización máis aló do que requirise o subministro das infraestructuras necesarias para unha eficaz administración e control das áreas de explotación. Baixo estas condicións, necesitaríase incentivar a configuración dalgúns núcleos urbanos que se erixisen en cabezas administrativas e concentrasen arredor de si o resto das comunidades circundantes que, esparexidas no medio rural en forma de vici ou aldeas, non participarían, sen embargo, das actividades de producción e intercambio que a Roma interesaba controlar. A estas vellas comunidades non se lles presentarían necesidades de cambio ou adaptación á nova orde, de aí a xustificación da pervivencia das estructuras sociais indíxenas na Gallaecia romana (1973: 227 ss.).

É neste estado de cousas onde atopaban o seu lugar as unidades prerromanas de organización xentilicia, as centurias, particular versión galaica das gentes/gentilitates do resto da Hispania céltica, que sobrevivirían como aquelas á reestructuración imperial ó seren reaproveitadas en prol da eficacia administrativa. A reutilización das institucións sociais preexistentes veríase aquí favorecida polo coñecemento da cidade, sistema perfectamente axeitado para asumir funcións económicas e defensivas. As centurias considerábanse como grupos de parentes unidos por lazos familiares en sentido extenso, pero desmembrados territorialmente, de xeito que a súa unidade só se reconstituiría por medio de contactos económicos (1973: 215).

Esta vaga definición das relacións predominantes entre os grupos de liñaxes presentábase como unha reacción á suxestión de J. Caro Baroja de identificar liñaxe e territorio, realidade que P. Le Roux e A. Tranoy só recoñecían no ámbito das

\footnotetext{
${ }^{14}$ A sospeita de que varios dos epígrafes votivos dedicados ós Lares Viales están ocultando crenzas relixiosas propias, decantaría as cifras cara unha maior representatividade das divindades indíxenas fronte ás romanas (1973: 217). Esta sospeita foi confirmada pouco despois por J.C. Bermejo (1978: 77-117). Este autor explica a interpretatio romana destas divindades como o desexo de contrapoñer o seu culto, popular e rural, ó dos Lares Compitales da Urbs, renovación culta e urbana do rendido a estes Lares.
} 
unidades superiores do tipo Gens Zoelarum ou para as cidades galaicas, en tanto que lugares de encontro para a defensa e os intercambios ${ }^{15}$.

Este primeiro bosquexo da organización das comunidades galaicas aparecía desenvolvido e completado nalgúns aspectos en traballos posteriores, manténdose fieis, en primeiras, á lectura proposta por Schulten: a centuria sería en todo caso o nome do clan na España do noroeste, tendo un princeps á súa fronte, a división territorial na que se pode recrutar 100 soldados aptos para a guerra ou escoller 100 individuos para establecer a base do imposto. Son os Galaici os que parecen portadores do sistema das centurias (Étienne et al., 1976: 100)

A existencia da centuria galaica empezaría sen embargo a cuestionarse pouco tempo despois debido ás críticas que ó respecto formularan diferentes investigadores en desacordo coa lectura de Schulten. Pero lonxe de atraer as posicións dos franceses, esas críticas desatarían un debate en torno ó significado do signo $\supset$ aínda non resolto.

Veremos de seguido cómo comezou a discusión entre, especialmente, P. Le Roux e A. Tranoy, dunha banda, e $\mathrm{M}^{\mathrm{a}} \mathrm{L}$. Albertos e G. Pereira Menaut da outra, desenvolvéndose logo coa participación doutros investigadores que serán presentados sobre a marcha do debate.

\section{1.a. Castella versus Centuriae. Un debate historiográfico}

Trala anterior etapa, sería Tranoy quen, entre os franceses, maior dedicación había prestar ó estudio das xentilidades galaicas (1981a). Conservando en principio a lectura centuria, este autor sería o primeiro en reconsiderar o problema da territorialidade destas comunidades como resposta á nova lectura presentada por $\mathrm{M}^{\mathrm{a}}$ L. Albertos. Segundo esta autora, o $\supset$, co significado de castellum/castrum, representaría a indicación da orixe dos individuos residentes nos castros galaicos e non as centurias ou calquera outros grupos xentilicios. Pola súa parte, A. Tranoy, ademais de seguir defendendo a existencia de centurias nesta rexión, retomaría a interpretación de A. Schulten da famosa inscrición de Bragança, pero cos matices introducidos por J. Caro Baroja. De acordo con esta lectura, a centuria relacionaríase directamente coa estructura familiar e social que corresponde á idea de cognatio,

\footnotetext{
${ }^{15}$ Os membros das familias que constituian as centurias podian estar esparexidas, mais gardaban lazos económicos co grupo. Por outra banda, para os intercambios e para a defensa, o burgo ou aglomeración xogaba o papel de lugar de reencontro e no momento en que Augusto emprende a conquista definitiva da rexión existen vilas reagrupando varias liñaxes [...] Así, o sistema estaba xa formado e parécenos poder concluír a ausencia de contradicción entre a existencia de cidades de tipo romano e unha permanencia da organización en liñaxes (1973: 215, n. 3).
} 
idea que expresa a noción de parentesco extenso e diferencia a gens destoutro tipo de agrupamentos, máis semellantes ás gentes e cognationes das que fala César para os xermanos (1981a: 374). A organización centuriada proporcionaría ademais os cadros fiscais e militares reaproveitados pola administración imperial para a recadación de tributos e o recrutamento de soldados, xogando por tanto un papel semellante ó que tiña a tribu para os romanos ${ }^{16}$. Para afirmar estes argumentos e ratificar o valor territorial das centurias apelaría tamén a algúns testemuños do que debían ser marcos limítrofes erixidos para delimitar os dominios correspondentes a cada unha delas (1981a: 375-6).

Observando a coincidencia no mesmo documento das formas $\supset$ e castellani (en tábula do Caurel, apén. epi. II. $n^{\circ} 3$ ), infire unha diferencia de contido entre elas correspondente ás dúas maneiras posibles de referir a origo das persoas, segundo o criterio parental ( $\supset$ Aiobaigiaeco) e residencial (castellani Toletenses ${ }^{17}$ ). Argüía contra os detractores das xentilidades galaicas a compatibilidade das dúas realidades, unha xeográfica/local e a outra étnica/social que, de ningún modo, terían por qué excluírense entre elas ${ }^{18}$.

A estas alturas da marcha do debate, xurdiría con forza a crítica de G. Pereira Menaut contra as teses dos franceses e os presupostos, epigráficos e históricos, sobre os que se viña construíndo a centuria galaica. No seu artigo: «Caeleo Cadroiolonis $f$. Cilenus $\supset$ Berisamo et al.: Centuria or catellum? A discussion» (1978), rebatería un tras outro todos os argumentos expostos en favor da lectura de Schulten. Comezaría relendo a inscrición da estela de Bragança, na que descubría un $S$ inédito un pouco á marxe do campo epigráfico visible. Á luz deste novo dato, proporía desenvolver o que consideraba abreviación de cognatio de (dicauit)

\footnotetext{
${ }^{16}$ A creación da centurias respectaría a organización xentilicia para mellor aproveitar unhas estructuras afíns ó que deberon ser as tribus romanas: chegado o momento, e tralo aproveitamento daquelas, Roma asimilaríaas e faríaas esvaecer, pero se o termo desaparece non obstante $o$ principio subsiste a través dos cultos indíxenas practicados no seo destas comunidades (1981a: $375,378)$.

${ }^{17}$ A referencia ó castro no canto de á centuria relacionábao Tranoy cos casos excepcionais nos que o Imperio transixiría coa permanencia dalgúns puntos fortificados que deberon manifestar a súa fidelidade ós conquistadores e aceptar a tutela de Roma, mesma razón pola que se toleraría a continuidade dos representantes da autoridade indíxena, como o princeps Albionum (ver apén. epi. I, $\mathrm{n}^{\circ} 10$; cf. 1981a: 375).

${ }^{18}$ Daríase aquí un caso análogo ó de Dalmacia, onde conviven divisións étnicas de base numérica (decurias) con castella (indicados sempre na epigrafía coas abreviaturas $k$, kast ou Cast, nunca $\supset$ ). Tamén a estructura dos epítetos teonímicos asociarían as divindades respectivas tanto a localidades como a grupos étnicos, testemuño da conservación, na sociedade galaica, dunha estructura en centurias incluso despois da desaparición do símbolo $\supset$ (1981a: 372, 378).
} 
cens(uit) (1978:274-5), aproveitando para derrubar a proba fundamental sobre a que se construíra a centuria galaica.

Os franceses, pola súa parte, non farían esperar a resposta ás puntualizacións de Pereira Menaut e, sen ceder demasiado ás críticas nin variar substancialmente as súas conclusións anteriores, de seguida presentarían unha reinterpretación do signo.

De partida, non aceptaron a existencia do problemático $S$ que, de existir, suporía un engadido ó texto orixinal, e consideraron solución desesperada a lectura proposta por Pereira para a estela de Bragança. Admitirían sen embargo agora que non aparecese na inscrición a palabra centuria (Tranoy e Le Roux 1984: $245^{19}$ ). Agás esta concesión ás críticas, non se terían retractado de ningunha outra consideración sobre a que incidira Pereira e manterían a mesma postura sobre o carácter xentilicio das comunidades galaicas ( $A$ vinculación a unha estructura de parentesco é dificilmente refutable, cf. 1984: 249).

Para estear esta afirmación, que permitía seguir defendendo o carácter xentilicio dos «grupos con $\supset$ », os franceses habían esgrimir os seguintes argumentos: habida conta da confusión entre as grafías $\mathrm{C} / \mathrm{G}$ en numerosas inscricións do s.I d.C. no noroeste, dado que a palabra cen[...] aparece incompleta e non se recoñece a presencia do $S$ na estela de Bragança, nada impide ler cognatio de centilitas (= gentilitas $)^{20}$. Se a isto engadimos que a procedencia da estela se localiza en territorio zoela, tampouco non resultaría estraña a relación do $\supset$ coas gentes/gentilitates tamén Zoelas do pacto de hospitalidade de Astorga, posto que a perfecta delimitación en época romana entre galaicos e ástures - entre os que se inclúen os Zoelas-, obedecería exclusivamente á demarcación político-administrativa imposta por Roma, quen non sempre respectaba divisións étnicas e culturais orixinarias. En definitiva, se Zoelas, xunto con Gigurros e Tiburos, parecen presentar en xeral maiores afinidades cos pobos da Gallaecia que cos do seu convento, sería posible establecer unha perfecta identidade entre as gentes e os grupos galaicos acompañados polo $\supset(1984: 252)^{21}$.

O tema das delimitacións étnicas caía de cheo no cerne da controversia, posto que o feito de as fontes situar ós Zoelas no convento ástur supuxo a proba irrevocable para algúns autores da marca da diferencia entre a área das xentilidades e a das

\footnotetext{
${ }^{19}$ A existencia do $S$ na estela de Bragança é ratificada por A. Rodríguez Colmenero (1988: 282), quen defende ademais a coetaneidade da letra co resto do texto.

${ }^{20}$ Ademais o texto de César sobre a cognatio e a gens xermánicas ofrecería un paralelo indiscutible na asociación dos dous termos (1984: 246-7, 253).

${ }^{21}$ A. Rodríguez Colmenero (1979: 215) era da mesma opinión: Tiburos e Gigurros parecen baixo todos os aspectos máis galaicos que ástures.
} 
comunidades con $\supset$. Por iso, a inclusión da estela na órbita do mundo galaico non se subtraería ás críticas dos autores partidarios da diferencia socio-cultural entre este mailo ástur. G. Pereira, especialmente, negaría rotundamente a posibilidade de relacionar realidades tan diferenciadas que en ningún aspecto poderían ser comparables, dado que Bragança non forma parte de Gallaecia [...] pertence a un contexto histórico diferente (1978: 274; da mesma opinión era J. Santos Yanguas, 1984: 79-81). Mais os franceses insistirían en que, na distribución das comunidades con $\supset$, tamén se incluían os pobos veciños do convento ástur (1984: 252; tamén A. Rodríguez Colmenero 1988: 181).

Continuando co debate, a aparición dun novo epígrafe no que $o \supset$ atopa a súa definición de xénero a través da concordancia co demostrativo eodem ${ }^{22}$-feito que inclinaría a balanza en favor do tamén neutro castellum - sería discutida por Le Roux e Tranoy alegando a incoherencia segundo a cal as gentes/gentilitates do pacto de Astorga aparecen tamén determinadas por medio dun demostrativo en xénero discordante (ex gente idem, idem gentilitas). En calquera caso, argüían, trataríase de fórmulas de repetición máis ben que de adxectivos neutros ${ }^{23}$.

O problema de indefinición que afecta en xeral ós nomes destas comunidades na epigrafía había ser moi discutido polos investigadores. Analizando outros exemplos, A. Rodríguez Colmenero suxerira que a concordancia de xénero puidera vir dada máis ben polo contido que polo significante do signo, pois [B]laniobrensi (apén. epi. I. $n^{\circ} 9$ ), adxectivo masculino ou feminino, non concorda cun substantivo neutro. E, de non ser así, tal vez puidese sobreentenderse a forma nada infrecuente genus, que denota o mesmo que gens. Así, no bronce de Luzaga en lingua celtibérica, aparecen varios genis asociados a xentilicios en xenitivo plural, de aí que fose posible propoñer para o $\supset$ este termo, logo genere eodem para a inscrición que se discute ${ }^{24}$.

En resposta precisamente á interpretación de Rodríguez Colmenero, $\mathrm{M}^{\mathrm{a}} \mathrm{L}$. Albertos (1988: 194) rexeitaría calquera analoxía entre as funcións desempeñadas polos correspondentes demostrativos no pacto zoela e no $\supset$ eodem [Eritaeco]. No

${ }^{22}$ apén. epi. I. $\mathrm{n}^{\circ}$ 13. A este exemplo habería que engadir o de hoc Tureobriga (apén. epi. I. $\mathrm{n}^{\circ}$ 26), que de facer referencia a unha centuria debería presentar o demostrativo feminino hac; cf. $\mathrm{M}^{\mathrm{a}} \mathrm{L}$. Albertos 1985: 306, n. 5; no mesmo sentido, G. Pereira 1982: 257.

${ }^{23}$ Ademais, moitas destas impropiedades gramaticais reflectirían as dificultades de adaptación da lingua indíxena á latina (1984: 250).

${ }^{24} \mathrm{O}$ demostrativo neutro, en calquera caso, faría referencia implícita a genus, aínda que expresamente se fale de gens/gentilitas; ademais idem acompaña a gentilitas no pacto dos Zoelas determinando o seu contido, non a forma (1988: 284). 
primeiro, idem só podería ter un valor equivalente a: "do mesmo xeito», «tamén», "analogamente», etc., mentres que $\supset$ eodem e hoc $\supset$ Tureobriga supoñen necesariamente un demostrativo neutro que modifica o substantivo tamén neutro que acompaña, castello, independentemente do xénero do topónimo a el aposto.

$\mathrm{O}$ enfrontamento de pareceres había seguir concentrándose no material epigráfico, especialmente na interpretación da tábula do Caurel. Así, G. Pereira (1978: 279-80) proporía identificar o contido de todos os termos que indican a origo nese documento: $\supset$ Aiobaigiaeco $=$ Lougei $=$ Castellani Toletenses, onde a primeira sería unha expresión estereotipada, en tanto que Lougei, non podendo referir unha unidade étnica tipo civitas, tería que identificarse necesariamente coa poboación do Castellum Toletum, de aí a lectura Lougei (qui et) Castellani Toletenses $^{25}$. Para os franceses esta solución non sería satisfactoria e, non aportando probas documentais en contra, seguirían mantendo que os Lougei, decididamente, formaban parte dunha comunidade máis ampla da asentada no Castellum Toletum (1984: 247-8). No mesmo sentido, pero con matices, se pronunciaría Rodríguez Colmenero (1988: 283), segundo quen a expresión en si mesma fai supoñer, ou que os Lougei ocupaban totalmente o castellum Toletum ademais doutros establecementos, ou que ocupaban parte do Castellum Toletense e áreas doutros similares. O sentido partitivo da expresión (do estilo Astures Transmontani, Celtici Supertamarici) deixa entrever que a comunidade dos Lougei comprendería máis individuos que os estrictamente asentados nese castro ${ }^{26}$.

Para rematar coa presentación dos derradeiros estudios presentados en defensa da centuria galaica, podemos salientar a nota común que conecta esta hipótese coa dos seus detractores. O feito de que as estructuras sociais indíxenas comencen a desintegrarse a fins do s.I d.C. - no sentido de que deixa de rexistrarse $o \supset$ con este valor na epigrafía- é explicado polos investigadores de acordo á combinación de distintos factores, mais non por iso deixan de coincidir todos nunha cuestión fundamental: tanto se as consideramos xentilicias como se non, as comunidades galaicas reúnen todas as condicións necesarias para unha asimilación directa e sen obstácu-

${ }^{25}$ Doutra banda, a regra xeral establecida por A. Tranoy (1981a: 375) segundo a cal as únicas abreviaturas correspondentes a castellum eran $K$, Kas, Kast, é rebatida por G. Pereira apoiándose na imprecisión que xeralmente afecta á epigrafía, chea de excepcións, de usos descoñecidos, de prácticas das que frecuentemente ignoramos a orixe. Tamén $\mathrm{o} \supset$, en contrapartida, posúe outros significados: caput, conductor, sextarius e contra na composición $\supset \mathrm{SC}=$ contrascriptor, conventus, etc. (1978: 279-80).

${ }^{26}$ A aparición da tábula da Civitas Lougeiorum (apén. epi. II. $\mathrm{n}^{\circ} 1$ ), coa que se identifica o pobo dos Lougei mencionado na do Caurel, confirmaría finalmente esta interpretación. 
los por parte da administración imperial, todo o cal resólvese recoñecéndolles, sexan centurias, sexan castros, a dimensión territorial que xeralmente se lles negaba ás gentilitates do resto da Hispania céltica.

Mentres G. Pereira argumentaba duramente en contra da centuria e, en xeral, contra calquera solución de tipo xentilicio para o signo, A. Tranoy e P. Le Roux remataban por rexeitar aquela, pero sen consecuencias importantes para o groso da súa interpretación. Esta reconsideración consistiu basicamente nun cambio de denominación xenérica para os grupos expresados mediante $\supset$, dos que a nova lectura excluía toda implicación que non atinxise exclusivamente ó seu carácter territorial e social: rexeitaban a división numeral herdada da lectura de Schulten e adoptaban definitivamente a relación $\supset=$ gens/gentilitas, compartindo, por tanto, a lectura que Rodríguez Colmenero viña defendendo ata o momento en solitario tras cuestionar tamén, pola súa parte, os procedementos mediante os cales se viña sustentando a chamada centuria, como recorrer a paralelos baseados en noticias pouco claras dos clásicos ou epígrafes afastados da área que nos interesa (facendo especial referencia ós paralelos establecidos coa Dalmacia, nos que se apoiaran primeiro Schulten e despois os franceses; cf. 1979: $240 \mathrm{~s}$.)

Mais non por rexeitar a centuria os seus antigos defensores habían variar, como se dixo, a consideración dos agrupamentos en $\supset$ como comunidades de carácter xentilicio. Dedicarase o seguinte apartado a presentar máis detalladamente o que se vén chamando a «hipótese xentilicia».

\section{XENTILIDADES NA GALLAECIA ANTIGA}

Como xa se espuxeron en parte os argumentos de Le Roux e Tranoy para acollérense á nova lectura, non nos deteremos demasiado na presentación das súas conclusións para dar cabida a outros autores que, dende distintos puntos de vista, defenderon no seu momento o carácter xentilicio da organización destas comunidades: A. Rodríguez Colmenero, A. Coelho da Silva e J. C. Bermejo. Cada un deles propoñía lecturas diferentes, aínda que dunha maneira que non contradicía en especial as hipóteses dos outros. En todos os casos considerábase que o signo $\supset$ aludía a unha institución de época romana que respectaba e reaproveitaba con fins fundamentalmente administrativos a realidade indíxena precedente. Fose gens/gentilitas, fose o castellum en que se asentaban os grupos xentilicios, fose census, todas as lecturas coincidían en opoñerse á aquela segundo a cal o $\supset$ referiría agrupacións puramente residenciais con valor institucional romano. 


\section{2.a. Gentes e Gentilitates}

A. Tranoy e P. Le Roux conviñeran definitivamente en que $o \supset$ adquiría significación na reorganización romana a través da conservación das formas indíxenas de organización socio-política nos cadros administrativos romanos. Este fenómeno, cualificado de «osmose», veríase favorecido polo feito de que as institucións indíxenas non resultarían absolutamente alleas á tradición política romana. As cidades, habitadas de xeito permanente ou non, posuirían funcións sobre todo relixiosas e de mercado e, accesoriamente, de sitios de defensa. Como lugares de reunión xogarían tamén o papel de centros políticos que, ó non estaren homoxeneamente repartidos nin seren igualmente importantes, tampouco non se poderían confundir cos castella. Estes, ademais de non coincidiren xeograficamente coa área máis restrinxida do uso epigráfico do $\supset^{27}$, non deberían considerarse como indicadores dun modelo socio-político de organización que levase a privilexiar erroneamente a forma de hábitat sobre calquera outro criterio na definición destas comunidades ${ }^{28}$.

Ese fenómeno «osmótico» do que se fala desenvolveríase dunha maneira particular, a partir da cal os franceses querían facer comprender o significado do signo. Este funcionaría como indicador da origo dos individuos, que por este medio expresarían o lugar de nacemento (natio) ou de residencia familiar (patria ou domus). Pero se hai que darlle un contido estrictamente romano ó signo, sería domo, verdadeiro substituto do $\supset$ na epigrafía (1984: 255; pola súa vez, o castro non era máis que unha das formas non urbanas de domus). A coincidencia das dúas expresións no mesmo epígrafe: Popilius Hirsutus Laucius (vel Lancius) $\supset$ domo Vacoeci (apén. epi. I. $\mathrm{n}^{\mathrm{o}} 27$ ) reflectiría un momento transitorio na condición xurídica destas comunidades, razón pola cal onde se refire domo habería que sobreentender gentilitas, noción que ten, pensaban estes autores, o mérito de permitir conciliar as estructuras de parentesco, o lugar da administración romana e a orixinalidade de Gallaecia (1984: 254-529).

\footnotetext{
${ }^{27}$ Por exemplo, Pintaius Pedilici f. orixinario dun Castellum Intercatia (CIL XIII 8098) é ástur transmontano (1984: 252).

${ }^{28}$ Para estes autores, a construcción historiográfica da «civilización dos castros», producto da reflexión decimonónica en torno á evidencia arqueolóxica do «castrexo», sería o fundamento da hipótese que tende a identificar o sistema político coa forma de asentamento (1984: 252).

${ }^{29}$ En opinión de G. Pereira, en ApilArqu/.../...D(omo)/ $\supset$ Acrip... (apén. epi. I. $\mathrm{n}^{\circ} 1$ ) o individuo estaría adscrito a unha comunidade referida por $D($ omo), e castello Acrip(a) sería o lugar de residencia, de modo semellante a como na segunda inscrición, [o discutido Lanci $\supset$ domo Vacoeci] a pesar da inversión dos «signos», o individuo expresaría a orixe por medio de $\supset$ Vacoeci e a adquisición da cidadanía de Lancia mediante D(omo) Lanci (cf. 1982: p. 255-6).
} 
O motivo polo cal a Gallaecia se concibía como unha rexión orixinal e diferenciada do resto da Hispania indoeuropea encontrábase, na hipótese de Le Roux e Tranoy, relacionado co sistema de parentesco cognaticio que rexería nos «grupos con د», considerado como o producto histórico dunha evolución que partiría dun nivel máis arcaico caracterizado pola filiación matrilineal -presente entre Ástures e Cántabros-. O emprego epigráfico do $\supset$ contribuiría a subliñar a orixinalidade da organización xentilicia galaica, que consistiría en ter acadado unha etapa de desenvolvemento máis adiantada que a dos pobos veciños ${ }^{30}$. Entre tanto, os castella e os vici iríanse impoñendo paulatinamente como centros administrativos, definíndose ó mesmo tempo que os municipios.

Xa dende os comenzos A. Rodríguez Colmenero fixera equivaler pouco máis ou menos as chamadas centurias ás gentilitates das inscricións do resto do norte peninsular (1972: 204). Pero cómpre antes de entrar nesta cuestión aclarar a interpretación que o autor facía da terminoloxía latina para intentar determinar con precisión os significados correspondentes ás categorías manexadas nas fontes antigas (regio, gens, genos, gentilitas, civitas, populus, etc.)

Nun primeiro momento Roma efectuaría as subdivisións administrativas en base a criterios de orde xeográfica, delimitando regiones que se supoñían configuradas de acordo coa homoxeneidade da paisaxe, o que non impediría que a regio romana coincidise con anteriores unidades políticas ou xentilicias prerromanas: Cada regio xeográfica pliniana é ocupada por unha gens; a gens que poboa unha regio é denominada tamén asi na epigrafía oficializante, Gens Vaccaeorum, Gens Cantabrorum, etc. (1979: 223-4). Pero máis que ningunhas outras, consideraba propiamente indíxenas tanto as divisións en civitates/populi como as subdivisións en gentilitates e, por suposto que non existiu na antigüidade prerromana a unidade xentilicia, estado ou reino dos Gallaeci, que abranguese as terras do noroeste que se estenden dende o Douro ó Cantábrico $^{31}$. Por outra parte, dependendo do estado da lingua e do momento histórico no que nos situasen as fontes, atopariamos termos aparentemente dispares pero que, ás veces, parecen reflectir a mesma realidade. Por exemplo, os éthne de Estrabón e a gens de Plinio, ou a gens da primeira parte do Pacto dos Zoelas, as comunidades en nominativo plural de Mela e os populi de Plinio, etc. Pero as

${ }^{30} \mathrm{O}$ sistema cognaticio era, en efecto, un sistema bilineal resultado dunha rica historia; distínguese do sistema matrilineal máis arcaico, pero ofrece combinacións bastante variadas segundo os grupos e as culturas (1984: 253).

${ }^{31}$ Prescindía da gradación xentilicia pobo, ou étnico maior, por considerala de carácter ficticio (1977: 260).

Cuadernos de Estudios Gallegos, Tomo LI, Fascículo 117, Santiago 2004. (Págs. 155 - 205) 
equivalencias propostas por Rodríguez Colmenero preséntansenos moito máis confusas ó comprobar que Apiano, por exemplo, cualifica de génos ós galaicos, e ós brácaros, subdivisión daqueles, como éthne. E complícanse aínda máis ó intentar identificar o génos coa syngéneia ${ }^{32}$, posto que, se os syngenesin numantinos son os compoñentes do génos dos arévacos, e o génos en Estrabón (III 3,7) se compón dos syngenòn establecidos nun poboado sen connotar un especial rango de parentesco próximo, non se entende que en Apiano o mesmo termo, génos, denote unidades extensas como a que forman os Gallaeci.

No tratamento das unidades inmediatamente inferiores establecíanse equivalencias no campo administrativo entre populus, civitas e oppidum, que se ben responden a diferencias xurídicas e conceptuais, de cara á administración reflectirían realidades semellantes ${ }^{33}$. Estas, ó cabo, conformarían as unidades básicas sobre as que Roma tería implantado a súa organización: aínda que o poboado (castellum) indique con maior precisión a referencia á orixe, a auténtica patria do galaico é a civitas, que encerra sobre todo unha significación territorial, debido ó limitado e disperso dos seus núcleos urbanos (1979: p. 235). A dinámica xeral seguida na configuración do novo mapa político tería como base a creación de unidades civitas co fin de potenciar as estructuras requiridas pola organización municipal, xa non no seo das regiones senón dos conventus (1979: 236). E polo que atinxe ós «grupos con د», Rodríguez Colmenero concluía que o signo anteposto ou posposto ás unidades que son fracción dunha civitas non é máis que unha maneira peculiar de expresar a gentilitas, propia de toda a área galaica, (1979: 243-4; en tanto que a gentilitas, como sub-fracción, se correspondería co resto dos xentilicios, ben se acompañesen de ex gente ou se expresasen mediante xenitivos de plural, 1979: 215-6; 226).

A achega quizais máis interesante de Rodríguez Colmenero a este tema refírese ó estudio das inscricións rupestres que presentan demarcacións, feitas por iniciati-

${ }^{32}$ En Apiano (Iber. 93) Nomantinois syngenesin, onde o noso autor entende do mesmo genos que os numantinos (1979: 225).

${ }^{33}$ É en Plinio onde populi, civitates e oppida parecen adquirir trazos semellantes, cando menos funcionais. Descritos en paridade de circunstancias, oppida e populi poden significar cousas diferentes cando aparecen mencionados conxuntamente referíndose a unha mesma gens pliniana (por exemplo, $H N$ III 26); o populus e a civitas responderían a unhas características similares, en tanto que oppidum introduciría trazos urbanísticos. No caso do noroeste a convivencia destes tres modelos organizativos diferenciados preséntase de xeito que os oppida conformarían os núcleos urbanos máis importantes dentro da unidade superior, civitas. A existencia de varios oppida para unha mesma civitas restaríalles autonomía pasando a depender daquela como comunidades contributae; cf. 1979: 231-5. 
va indíxena e sen intervención romana, de circunscripcións territoriais entre algunhas das comunidades antigamente asentadas nos arredores de Aquae Flaviae ${ }^{34}$. A partir dos nomes que parecen conservados, ben na forma íntegra do nominativo plural: Praeni/Coroqui, Treb(?)/Obili, ben na de posibles xenitivos plural: Ripau(m)/ Puac(um), infería a presencia de grupos propiamente xentilicios e desvinculados de calquera referencia toponímica. O único caso no que sería posible supoñer a coincidencia xentilidade-castro, se ben non con absoluta seguridade, é o dos Coroqui e Praeni, no sentido de que os varios termini a eles referidos parecen delimitar os territorios circundantes de dous antigos castros existentes na zona (1988: $274 \mathrm{ss}$. $)^{35}$. En todos os demais casos a proliferación de asentamentos castrexos asociables ós grupos correspondentes dificultaba a identificación cun asentamento determinado. Por outra banda, o epígrafe no que se mencionan conxuntamente varios grupos acompañados do signo: $\supset M / V \supset M / A \supset S$ e que, suponse, compartirían o mesmo castro, confirmaría a idea de que os castella non poden confundirse coas comunidades referidas polo signo (1988: 285). Para Rodríguez Colmenero os castella galaicos representarían tamén unha forma de asentamento entre outras, sen maior importancia para a organización social indíxena que a de funcionaren como centros residenciais, razón pola cal serían, como os $\supset$, as domus e máis o étnico da civitas adxectivado, referentes da origo dos individuos. Só sería posible atribuír valor toponímico a formas como Castello Berense, Meidunio, Intercatia, nos que a referencia ó castro ou lugar de residencia do individuo é explícita. O feito de que houbese unha expresión diferenciada para o lugar de residencia confirmaría a referencia a unha realidade tamén diferenciada. $O$ realmente importante, en calquera caso, sería determinar o contido, xentilicio ou territorial, da referencia dada (1988: 281-2).

Volvendo sobre a interpretación da estela de Bragança, Rodríguez Colmenero ratificara, como xa se dixo, a existencia do problemático $\mathrm{S}$ final que os franceses rexeitaran e, en base a el, proporía a seguinte lectura: Cognatio de(dicavit) gen(tili) $s($ uo). Esta lectura convén á hipótese segundo a cal o termo que traduce o significado do «c invertido» non pode ser outro senón «cognatio», a forma de parentesco transmitida por vía preferentemente matrilineal: genus e, aquí, o seu derivado

\footnotetext{
${ }^{34}$ Estes termini posuirían un carácter absolutamente orixinal dentro da Península. Descoñecidos fóra do noroeste hispano, carecen de calquera indicio de oficialidade que os faga confundir con outros termos, augustais, demarcacións de prata militares, etc. (1988: 271).

${ }^{35}$ Para A. Coelho da Silva (1986: 275) estes marcos delimitarían as terras de labor traballadas polas dúas xentilidades que comparten o mesmo castro, pero ocupando sectores distintos e ben delimitados.
} 
adxectivo gentili. Genus tería ademais a vantaxe de contar con paralelos na área celtibérica e ástur ${ }^{36}$, de concordar en neutro co demostrativo eodem (genere eodem), pero tamén co feminino dalgunhas comunidades, por exemplo $\supset$ Narelia, ó equivaler a gens/gentilitas, posto que a agnación predominante nestes grupos tampouco non estaría ausente das agrupacións referidas por genus. A ambivalencia da expresión xustificaría igualmente a inversión do signo. En definitiva, a clave para interpretar o signo $\supset$ reside en que baixo o mesmo, préstamo da epigrafia romana e puramente artificial, agáchanse as nocións de genus, gens, gentilitas, para designar a estirpe ou procedencia sanguinea (1988: 285-88).

A diferencia da postura de Rodríguez Colmenero con respecto á dos franceses, como vemos, non era radical senón máis ben de matices. O un e os outros propoñían unha reconstrucción do proceso de integración das comunidades indíxenas no mundo romano de acordo cunhas directrices que, en xeral, non se discutían. Non había variación no que se refería á forma de entender o proceso de constitución das civitates nin da reorganización política e administrativa dos populi indíxenas, ó coincidiren, basicamente, na idea do reaproveitamento das estructuras sociais das comunidades prerromanas por parte do sistema político-administrativo romano. Había acordo en considerar referencias á origo persoal calquera das posibles indicacións de procedencia, fose territorial ou xentilicia: civitas, $\supset$ ou castellum, un dos puntos fundamentais das discrepancias con respecto ós defensores da lectura de $\mathrm{M}^{\mathrm{a}} \mathrm{L}$. Albertos.

Con isto rematamos de presentar algunhas das interpretacións que ademais de defenderen o carácter xentilicio dos grupos con $\supset$, achegaban a sociedade castrexa do noroeste ó resto das gentes/gentilitates hispanas. Outros autores, como A. Coelho

\footnotetext{
${ }^{36}$ Belaiocum genis do bronce de Luzaga e a estela funeraria dedicada a un vadiniense por Origenus, cognato suo (loc.cit.). Sen embargo, a identificación do celtibérico genis con genus presenta problemas. Mentres $\mathrm{M}^{\mathrm{a}} \mathrm{L}$. Albertos (1975: 65) opinaba que Os romanos deberon traducir por gentilitates, ou gentes os nomes dos clans indixenas, que quizais en celtibérico se dicía genis ( $c f$. Belaiocum genis, en Luzaga) e acaso en lusitano cori (cf. Veamini cori, de Lamas de Moledo), M. Faust (1979: 440) sostiña que contra a interpretación, no bronce de Luzaga, de cenis como gentilitas, fala que ali a palabra aparece ligada dúas veces a un xenitivo singular, e só unha vez ó xenitivo plural. Este sería o mesmo termo que, segundo este autor, vemos aparecer abreviado como «g» nas fórmulas onomásticas que transcriben ó alfabeto latino a forma indíxena «ce», o indicativo de filiación nas inscricións celtibéricas, que se corresponde co «f» das escritas en latín. Con todo, aínda que sobre a traducción destas abreviaturas por «fillo, descendente» non parece haber ningunha dúbida, hoxe en día considérase que o termo que abrevian non é kenis senón kentis. Ver Beltrán, $\mathrm{F}$, Hoz, J. e Untermann, J., 1996: 119. Entre tanto, aínda que etimoloxicamente emparentado, o significado concreto de kenis permanece indeterminado. F. Villar (1995: 101, n. 41) propón, en función do contexto, dúas acepcións: «familia»e «pobo».
} 
da Silva e J.C. Bermejo, insistirían tamén na orientación xentilicia das comunidades galaicas. A eles dedicaremos os seguintes apartados.

\section{2.b. $\supset$ : o Castellum como unidade suprafamiliar}

A. Coelho da Silva mantiña unha lectura particular do signo $\supset$ que non contaba con ningún outro defensor entre os estudiosos do tema ${ }^{37}$. Partía en principio de que a organización social castrexa estaba baseada en lazos de sangue, aínda que dunha maneira diferente á das demais sociedades de tipo xentilicio da Hispania céltica propiamente dita $(1985 ; 1986)$. Entendía que a unidade social básica era o grupo doméstico, que atopaba a súa plasmación arqueolóxica nas subdivisións espaciais practicadas no interior dos chamados «barrios» castrexos, conformando os núcleos dentro dos cales se asentarían os membros dunha familia extensa. Esta unidade social corresponderíase coa syngéneia referida por Estrabón (III 3,7), o grupo de parentes reunidos na celebración de banquetes nas casas colectivas con bancos pegados ós muros, tamén documentadas arqueoloxicamente perfectamente integrados en núcleos familiares. En tanto que familias extensas, estes grupos serían diferentes das gentilitates dos Zoelas, que consideraba como «comunidades de liñaxe». En proba da existencia desa familia atopariamos as dúas inscricións da citania de Briteiros: Coroneri Camali domus e Camali domi Caturo, segundo as cales a casa-familia de Coronerus abranguiría ós membros da familia por ascendencia (o seu pai Camalus) e descendencia, consanguinidade e afinidade, un dos cales (Caturo) poderá estar referido na segunda lápida, o que permitiría ademais identificar a syngéneia coa domus, a «casa», entendida en sentido social (1985: 201-6; 1986: $\left.268-9^{38}\right)$. A reunión no castro de varios destes grupos vinculados entre si pola descendencia dun antepasado común, daría lugar á unidade suprafamiliar que Coelho da Silva identifica co castro mesmo, como unidade territorial. Aquí radica a peculiaridade da lectura deste autor, posto que se ben admitía que o signo representase a pertenza ó castellum, a este considerábao integrado por liñaxes e organizado, por tanto, á maneira dunha comunidade xentilicia ${ }^{39}$. A única diferencia

\footnotetext{
${ }^{37}$ Alomenos dende que $\mathrm{M}^{\mathrm{a}} \mathrm{L}$. Albertos (1975: 50, n. 7) abandonara a idea-que seguía a F. López Cuevillas e R. Serpa Pinto- da posible correspondencia entre clans - ou xentilidades- e castros, como anteriormente mantivera tamén A. Schulten, 1962: 60.

${ }^{38}$ Sobre a capacidade das casas colectivas, calculaba entre 20 e 50 membros para cada un desas unidades familiares, que consideraba semellantes á zadruga eslava, con tantas familias restrinxidas cantos fillos viven no lar común.

${ }^{39} \mathrm{O}$ intento de harmonizar a lectura castellum coa pervivencia dunha estructuración social de base xentilicia posúe un antecedente en M. Villanueva Acuña (1984: 198), quen pouco antes afirmara: dado o mundo no que Gallaecia está inmerso de influencia céltica, e o grao de evolución da súa
} 
que se destacaría con respecto ás gentilitates dos Zoelas consistiría en que as unidades suprafamiliares equivalentes a aquelas na área castrexa se identificarían polo nome do castro (1986: 272, 276-7).

Pero a exposición de Coelho da Silva presenta a situación dunha forma bastante máis confusa, posto que na súa interpretación as comunidades de liñaxe que se designan mediante o castellum poderían convivir con outros grupos semellantes no mesmo asentamento (1986: 276). A confusión resulta de querer conciliar a equivalencia $\supset=$ castellum coa organización social en grupos de descendencia tan reducidos que ben puideran ocupar, na súa opinión, cada un dos «cuarteiróns» nos que se distribúen as estructuras habitacionais dos castros do noroeste, especialmente na área castrexa da bracarense estudiada por el mesmo. Neste caso os nomes que acompañan ó $\supset$ na epigrafía aludirían a grupos diferenciados dentro do mesmo castro e asentados en cadanseu «cuarteirón», co cal a identidade $\supset=$ castellum non posúe moito sentido.

\section{2.c. Unha lectura diferente: Census}

Unha nova solución para a interpretación do signo fora proposta por J.C. Bermejo no artigo "Variaciones sobre el tema de la centuria» (1978-1980), publicado cando a lectura de Schulten gozaba aínda da aceptación de boa parte dos investigadores. Se ben a posibilidade da existencia das centurias no interior da sociedade galaica chegou con este traballo a adquirir maior verosimilitude da que chegaran a imprimirlle os seus defensores anteriores, decidiuse darlle tratamento a parte neste apartado porque se adiantaba unha interpretación nunca proposta con anterioridade: a posibilidade de entender no signo o termo census.

A idea principal que se desprende da interpretación de Bermejo é que o signo estaría a referir a implantación sobre as comunidades do noroeste ibérico dunha institución administrativa romana na que aínda se poderían descubrir os trazos da vella estructura xentilicia das sociedades indíxenas. Por outra parte, sempre que introducísemos os matices oportunos, nada impediría seguir a considerar $o \supset$ como centuria, sobre todo no que respecta á configuración interna destas unidades organizativas, que non teriamos necesariamente que considerar como formadas por 100 membros, como pensaban Schulten ou Adrados, senón por un determinado número de gentes, entendendo este termo latino no seu sentido restrinxido, é dicir, como familia extensa ou «casa» (1978-1980: 106).

cultura, non nos parece posible resolver de xeito negativo o artellamento da sociedade do noroeste en torno a unidades de parentesco.

Cuadernos de Estudios Gallegos, Tomo LI, Fascículo 117, Santiago 2004. (Págs. 155 - 205) 
A posibilidade de ler census alí onde antes se propoñía centuria, xustifícábase considerando que as centurias constituían na orixe as unidades censatarias de carácter territorial nas que se clasificaba á poboación romana antiga trala institución do census, coa reforma de Servio Tulio (1978-1980: 109). Se a constitución das comunidades galaicas lembrasen dalgunha maneira a vella organización social e territorial do sistema serviano, entenderíase que o goberno imperial decidise denominalas co termo correspondente ó sistema social que nelas se vise, ou parecera verse, reproducido ${ }^{40}$. Casos paralelos desta reutilización do indíxena teríanse dado, polo demais, noutros moitos lugares do Imperio, caso das curiae británicas ou dos pagi británicos e galos, que constituíron as unidades políticas e administrativas para o recrutamento de tropas, imposición de tributos, etc., durante a dominación romana. $\mathrm{O}$ feito de que nestes países as levas de soldados para os corpos auxiliares das lexións e a recadación de tributos se encadrasen no marco destas agrupacións, permitía supoñer que serían estas unidades organizativas as que serviran de base para a elaboración dos censos da poboación indíxena, e que unha institución análoga á destas comunidades celto-romanas fora establecida aquí sobre a base do census imperial e cos mesmos obxectivos (1978-1980: 107, 111-2).

Os censos imperiais das provincias elaborábanse con fins eminentemente fiscais e a algún dos efectuados en tempos de Augusto posiblemente aludirían as cifras de poboación transmitidas por Plinio (HN III 28) para os conventos do noroeste hispano (1978-1980: 114). Estas cifras recollerían o número de contribuíntes ós impostos de capitación probablemente recadados no noroeste, a semellanza doutras provincias ou territorios de recente conquista nos que as dificultades para avaliar as propiedades raíces complicaban a imposición regular dos tributa soli e capitis recadados nas zonas máis romanizadas do Imperio. Os impostos de capitación neses territorios eran normalmente considerados como marcas de servidume e foron establecidos, a parte de naquelas rexións que os viñan padecendo anteriormente á conquista romana, entre outros pobos aínda pouco integrados e normalmente rebeldes, caso dos bretóns e do pobo xudeu, que contaba cunha tributación particular (1978-1980: 116).

En definitiva, dada a tendencia do Imperio a respectar as institucións orixinarias de cada pobo co fin de facilitar a súa mellor administración e goberno, sería probable que as comunidades galaicas susceptibles de seren organizadas en centurias

${ }^{40} \mathrm{Se}$ o afán restaurador de Augusto das vellas institucións republicanas atopase na Gallaecia un bo campo de aplicación, ben podería ter realizado un traslado máis ou menos aproximado deste sistema [das centurias] no noroeste da Península, na que coñeceu unha sociedade arcaica como a Roma da época dos Reis (1978-1980: 115). 
non fosen máis que agrupamentos indíxenas previamente dotados dun marcado carácter social, político e territorial, sendo por esa razón facilmente reutilizables e asimilables pola administración romana, especialmente despois de proceder á súa habilitación como circunscripcións fiscais. Coidamos que neles [nos censos] se agrupou á poboación utilizando unhas institucións xentilicias indíxenas. Á fronte de cada unha delas situouse probablemente un antigo xefe indíxena, que se faría responsable do cobro de impostos na súa unidade e da súa entrega á administración romana, e quizais tamén dalgún tipo de recrutamento de soldados para as unidades auxiliares do exército romano (1978-1980: 114).

Debido á que o debate historiográfico sobre o significado do signo se había centrar exclusivamente en torno ás lecturas xentilicia e castellanista, a hipótese presentada por J.C. Bermejo non había ter continuidade en estudios posteriores, ata que en datas recentes P. López Barja (1999) retomara a suxestión de que o signo puidese estar reflectindo a conversión romana dos castella galaicos nas unidades sociais indíxenas que servían de base para a elaboración dos censos. A razón de que os castella se mencionen nas inscricións non tería nada que ver coa indicación da origo, posto que esta refire o vínculo administrativo que unía ós cidadáns cos seus respectivos municipios e non a simple indicación de residencia ou lugar de orixe. Debido a que os castros nin eran municipios, nin os seus habitantes cidadáns romanos, senón peregrini, os castella galaicos non poderían, en consecuencia, seren indicadores de origo. Isto non impediría, sen embargo, que tivesen funcionado como tales, debido sobre todo á inexistencia no noroeste de cidades que asumisen as responsabilidades censatarias e fiscais que correspondían ós municipios. Os castella terían, daquela, funcionado como as unidades mínimas de referencia para a elaboración dos censos e a recadación de tributos con anterioridade ó século II d.C., momento a partir do cal comenzarían a emerxer no noroeste os municipios (os novos indicadores da origo) e empezarían a abandonarse os castros. En definitiva, a desaparición do signo epigráfico sería a expresión da culminación deste proceso.

A proposta deste autor, a semellanza da que nos ofrece Coelho da Silva, posúe o mérito de tender unha ponte entre as dúas lecturas tradicionais enfrontadas, posto que a pesar de afirmar a identidade do signo coa referencia ós castella, tamén admite a posibilidade da existencia entre as poboacións castrexas dunha simbiose entre parentesco e territorio.

Con isto remata a presentación dos estudios máis destacados na liña dos defensores da «hipótese xentilicia», adiantando ó mesmo tempo a través de P. López Barja a presentación da tese á que partir de agora nos referiremos como «hipótese castellanista», que se considerará de seguido. 


\section{CASTELLA, COMUNIDADES POLÍTICO TERRITORIAIS}

Algúns aspectos da interpretación do «c invertido» co significado de castellum xa foron expostos nun apartado anterior a propósito do debate mantido en torno ó tema. Mais, como este continuamente se nutre de novos descubrimentos e novos datos, cómpre tratar de xeito máis detallado as ideas e interpretacións esgrimidas na defensa desta hipótese.

Como dixemos, débese a $\mathrm{M}^{\mathrm{a}} \mathrm{L}$. Albertos a proposición desta lectura, que é hoxe a máis difundida e aceptada por parte dos estudiosos da Hispania antiga. De entre eles, aquí destacaremos especialmente as contribucións de J. Santos Yanguas, G. Pereira Menaut e M ${ }^{\mathrm{a}}$ Cruz González, sen esquecermos o labor de F. Beltrán Lloris, aínda que non aporte nada novo á presente lectura e o seu traballo se centre principalmente na crítica á aplicación da teoría clásica xentilicia no estudio das sociedades antigas.

$\mathrm{Na}$ obra de $\mathrm{M}^{\mathrm{a}} \mathrm{L}$. Albertos domina a idea da diferencia esencial entre os pobos organizados en gentes e gentilitates - habitantes da Meseta e norte peninsular-e aqueloutros que, en primeiras, considerara organizados en centurias, os Galaicos. Seguindo a A. Tovar, esta autora distribuíra a área indoeuropea de Hispania de acordo coa ocupación consecutiva do territorio peninsular por parte de distintas vagas invasoras de pobos indoeuropeos. Os primeiros pobos desta orixe asentados na Península terían sido os Ástures, Cántabros, Pelendóns, Carpetanos e Vetóns, e a eles correspondería a organización en xentilidades, plenamente vixente aínda en época imperial debido á súa condición marxinal con respecto ós pobos afincados con posterioridade na Celtiberia tras unha nova invasión de carácter máis puramente céltico (1975: 19-20).

Sobre a constatación do predominio na área das gentilitates de nomes xentilicios en xenitivo de plural e estreitamente ligados á antroponimia indíxena, chegouse á conclusión de que os étnicos menores reflectían no seu nome a designación de grupos de parentes identificados polo nome dun antergo común: un xentilicio como Toutoniqum referiríase ó conxunto dos descendentes dun Toutonus, por exemplo (1975: 25). Pero a Gallaecia, tamén afectada por estes movementos de poboación, só conservaría a lembranza daquela antiga organización xentilicia nos seus teónimos, que traducirían a través dos seus epítetos a vinculación destas divindades cos antigos clans galaicos e os castros que ocupaban. Ó seren suplantados pola organización en centurias imposta polos invasores, aqueles vellos clans permanecerían soamente como «fósiles» nos epítetos das súas divindades (1975: $52,61-2)$. 
Estas diferencias serían establecidas en base a criterios fundamentalmente lingüísticos, os mesmos que, baixo un enfoque distinto, permitirían a Albertos inferir un significado diferente para o signo: as supostas centurias, precedidas da preposición ex(s) e con nomes en ablativo de orixe, non podían senón referir a origo, é dicir, a pertenza dos individuos á localidade de orixe, o que no noroeste peninsular se correspondería co castellum. A formulación da nova hipótese estableceuse de acordo cos argumentos que agora se resumen (cf. 1975: 63-6; 1977: 20 ss.):

- É un feito comprobado que o $\supset$ pode aparecer referindo a origo das persoas en zonas do Imperio carentes de organización xentilicia cando, pola contra, non se dan casos nos que as gentes/ gentilitates se mencionen alí onde aquela está ausente.

- Non podemos asignarlle con exclusividade ó signo o valor de centuria posto que, ás veces, oculta outros significados, como conventus.

- A antiga interpretación (1975: 34) dos nomes de comunidades formados sobre unha base -obri- e un sufixo -co invariable, dá paso agora ó recoñecemento dun sufixo brix/briga con significado toponímico en todos os casos, solución que tamén se aplica ós epítetos teonímicos que presentan a mesma estructura (por exemplo Lansbrica, asociado a Bandua).

- Por outra parte, a coincidencia entre os nomes destas antigas comunidades con topónimos actuais e as mencións asociadas ó signo ( $\supset$ Talabriga, apén. epi. I. $\mathrm{n}^{\circ} 24$ ) con outras en ablativo de orixe en -ensis (Talabrigense, etc), permite igualmente identificar estas comunidades con núcleos habitados.

- Constátase no mesmo texto a referencia explícita a castellum e a presencia do signo $\supset$, inexplicable se o interpretamos como «centuria».

- O caso concreto da inscrición Popilius Hirsutus... Lauci(us?) domo Vacoeci (apén. epi. I $\mathrm{n}^{\circ}$ 27) expresa o étnico ou nome da tribo con Laucius, mentres que o topónimo Vacoeci aparece reforzado mediante o signo e a palabra domo.

Os argumentos aquí expostos en favor da interpretación dos "grupos con د》 como entidades de carácter territorial identificadas con castros, serían retomados por todos os autores que defenden a lectura do signo co significado de castellum. Sen embargo, os seus seguidores convirían en introducir nesta hipótese un matiz que se virou fundamental na xustificación da rápida asimilación das comunidades galaicas por parte da administración romana. Esta asimilación non concordaría coa pervivencia, sequera fósil, de grupos xentilicios no seu seo, como pensaba 
Albertos $^{41}$ : a organización política indíxena habíase diluír axiña nos cadros administrativos romanos porque os castella galaicos participaban dun sistema organizativo moi semellante á civitas romana. Partindo deste suposto, os investigadores tenderían case exclusivamente a incorporar novos epígrafes ó esquema prefixado da territorialidade e da preeminencia dos castros nas formas organizativas indíxenas da Gallaecia. Nesta liña sitouse, entre outros, o traballo de J. Santos Yanguas.

Este autor buscou diferencias fundamentais entre as xentilidades e a realidade representada polo $\supset$-non xentilicia ó seu parecer- comparando as táboas de hospitalidade do Caurel e de Astorga. Dado que tanto entre os uns como entre os outros os romanos terían instaurado os seus cadros organizativos aproveitando o preexistente, habería que deducir unha diferencia organizativa previa á incorporación de senllos ámbitos culturais no Imperio. Malia coincidiren na data de redacción a primeira parte do pacto zoela e a do Caurel (27 e 28 d.C. respectivamente; ver apén. epi. II. $n^{\circ} 3$ e 4 ), distinguiríanse nos dous documentos a pervivencia de institucións indíxenas no primeiro e un reflexo da realidade administrativa romana no segundo (1984:14). A liña argumental desenvolveuse nos seguintes termos:

A gens Zoelarum do ano 27 d.C. tería o mesmo rango en principio que a dos Visaligi ou a dos Cabruagenigi, pero unha vez que aquela gens adquiriu suficiente extensión e importancia (situación reflectida no pacto de 152 d.C.), incluiría no seu ámbito de influencia a outras pequenas gentes coas súas respectivas gentilitates, funcionando xa como unha auténtica civitas. Entre as xentilidades menores que a compoñían, as relacións de parentesco instituirían os cadros xurídicos e relixiosos que mediaban a integración na civitas/populus, verdadeira unidade política (1984: 7-19). É de destacar na caracterización que Santos facía desta sociedade xentilicia a definición territorial dos distintos grupos que, se ben non atopaba claramente nas fontes epigráficas ou literarias, deducía do proceso de adaptación ás institucións romanas. O termo que segue a gens (Pembelorum, Ratrium, Ablaidacorum, Visaligorum, etc.) expresaba a unidade indíxena e á vez o territorio que esta unidade ocupaba, polo que o territorio da unidade superior debía englobar os territorios correspondentes ós dos seus compoñentes menores $(1984: 12,17)$.

\footnotetext{
${ }^{41}$ A diferencia dos seus seguidores, Albertos non deixou de defender a pervivencia dos clans no ámbito dos castella, posto que consideraba que a maioría dos deuses indíxenas podían ser protectores de castros e poboados (especialmente os cualificados mediante un epíteto formado co elemento -briga), pero tal vez tamén dos clans ou quizais das dúas cousas ó tempo (os cualificados mediante epíteto formado co elemento -aeco; 1977: 21)
} 
A adscrición das comunidades galaicas ás súas inmediatas superiores coincidiría enteiramente co proceso analizado para as gentes. O populus funcionaría tamén aquí como unidade integradora das distintas comunidades menores que, sen embargo, non se vinculaban mediante lazos de parentesco, senón que, como núcleos urbanos, rexiríanse por relacións de veciñanza local: a realidade representada polo signo $\supset$ e o termo en ablativo que lle segue, sexa cal for o significado que se dea ó signo, pode ser ou ben indixena, aínda que non xentilicia, ou ben, máis verosimilmente, unha realidade administrativa romana partindo da organización indixena (1984: 27).

No intento por contrapoñer estes sistemas sociais, organizacións indíxenas por unha banda, e organizacións político-administrativas pola outra, J. Santos só recoñecía a pervivencia das primeiras nas gentilitates da primeira parte do pacto zoela no nivel da unidade inferior (gentilitas Desoncorum e Tridiavorum, que equiparaba a algúns dos oppida de Plinio), así como, no nivel seguinte, na gens Zoelarum da primeira parte do mesmo documento, facéndoa equivaler a algúns dos nominativos plural de Mela (Grovii, Praesamarchi, etc). Derívase disto que a permanencia de estructuras propiamente prerromanas non se detectaría entre os galaicos nas unidades inferiores, posto que, xunto ás gentilitates e gentes do pacto renovado do ano 152, xentilicios «en -um» (v.g. Oilaridum) e algúns oppida de Plinio (oppidum Noega, Abobrica...), os castella, así expresados ou mediante o $\supset$, respondían ós esquemas da reorganización administrativa romana, axiña desaparecidas en favor do nivel político-administrativo básico, é dicir, a civitas (1984: 31-40).

O característico nunha organización en $\supset$ sería que as relacións de consanguinidade esvaeceran fronte ás impostas pola residencia, e nisto radicaría a diferencia fundamental con respecto ás xentilidades.

Polo que atinxe ás unidades de $3^{a}$ orde, mentres que na praxe administrativa romana aparecen perfectamente definidas configurando os chamados conventus, para a organización prerromana, segundo Santos, resulta practicamente imposible atopar unidades correlativas que englobasen dalgún xeito (en base a unha xerarquía política ou ó recoñecemento dunha identidade étnica) e con algún fin, unidades inferiores ou populi. Subscribindo a idea da inexistencia das tribos, este autor rexeitaba a posibilidade de que nestes pobos houbese conciencia de unidade entre os grupos que conformaban unha regio ou gens pliniana. Sen embargo, presentaríanse situacións excepcionais nas que estas poboacións se verían inducidas a agrupárense en confederacións tribais, caso dunha ameaza externa, ou con motivo dunha incursión de rapina en zonas de economía agrícola máis próspera, etc. (1984: 44 ss.). Rexéitase, así, falar de tribos sen descartar que, baixo circunstancias extremas e con fins militares ou de supervivencia, distintas gentes unisen 
esforzos nunha confederación que, aínda que non se considera solidamente instaurada, si potencialmente constituíble. J. Santos afirmaba ademais atopar paralelos na evolución interna testemuñada noutras poboacións neste mesmo estadio de evolución, que nos levan a propoñer a posibilidade de que esta unidade de $3^{a}$ orde estivese en vías de constitución (1984: 44).

En definitiva, calquera que fose o carácter orixinario daquelas, o que interesa destacar é que, ó estaren organizadas en castella, as comunidades galaicas presentaban todas as vantaxes para facilitar unha rápida incorporación no marco políticoadministrativo da civitas, razón pola cal os $\supset$ terían desaparecido da epigrafía moito antes que as gentes e os xentilicios en -um ástures, que persisten ata o s. III d.C., mentres aqueles desaparecen durante o proceso de municipalización do noroeste trala concesión do Ius Latii por parte de Vespasiano no último tercio do s. I d.C. (1984: 82 ss.)

No que atinxe ó tratamento das comunidades indíxenas do noroeste neste traballo de J. Santos pouco máis poderiamos engadir, agás que, no fundamental, coincide coa interpretación que ó respecto facían todos os defensores da lectura de Albertos e, de modo especial, G. Pereira Menaut.

Cómpre salientarmos agora o papel que entre os defensores da identidade $\supset=$ castellum xoga a noción de origo persoal, posto que en función dela determinábase a pertenza dos individuos a unha localidade concreta, ó tempo que se excluía a posibilidade de que, pola mesma fórmula, se fixese referencia a unha xentilidade.

A presencia da formulística latina que expresa na epigrafía do noroeste a origo dos individuos fora analizada por J. Santos e G. Pereira nun artigo conxunto (1980), e as súas conclusións retomadas noutros traballos feitos por separado. Seguindo algunhas apreciacións de Sereni, segundo quen a mención da origo aparece na epigrafía lígur marcando o tránsito da sociedade xentilicia a outra de tipo territorial, baixo a coacción de Roma (1980: 126 ${ }^{42}$ ), e retomando a definición da noción de origo de Nörr, que coincidía en negar a súa compatibilidade coa referencia ó grupo xentilicio, propoñían para os «grupos con つ» unha orixe administrativa romana con carácter político-territorial e a imposibilidade de que se tratase en ningún caso dunha forma de organización social indíxena. Neste artigo defendíase

${ }^{42}$ As fórmulas das inscricións [lígures] teñen unha estructura similar ás que estamos analizando. Segundo Sereni, a mención da origo aparece cando se disolve a sociedade xentilicia e un número de persoas procedentes de diferentes grupos se asentan en comunidades de tipo territorial baixo a coacción da potencia romana. Estes asentamentos son denominados na Sententia Minuciorum da Tavola de Polcevera, expresamente, castellum e os seus habitantes castellani, cf. Santos, J., 1984: 27. 
que a mención do $\supset$ expresaba a origo persoal en todos os casos, e supoñíase que por este medio a administración romana dispoñía dun instrumento eficaz de control en comunidades tradicionalmente rebeldes nunha zona de máximo interese estratéxico (económico) para o conquistador (1980: 12743). Pero máis tarde G. Pereira (1982), ante a aparición dun epígrafe no que o signo se presenta acompañado da fórmula I.O.M (apén. epi. I. n ${ }^{\circ} 6$ e 20) habíase retractar da suposición anterior de que todos os signos indicaban a origo persoal, para, a partir do novo dato e da constatación de que fóra da Gallaecia os grupos sociais menores non parecen nunca facer estes tipo de dedicacións, establecer outro criterio diferenciador das nosas comunidades.

A medida que se avanzaba no desenvolvemento do debate en torno á lectura e interpretación do signo epigráfico, adiantabamos algunhas das consideracións que levaran a este autor a cuestionar a existencia da organización centuriada no noroeste hispánico. Tras este primeiro momento, e establecida a preeminencia do castro sobre calquera outro esquema organizativo na definición socio-política desas comunidades $^{44}$, G. Pereira había concentrar todos os seus esforzos en intentar particularizar a cultura da Gallaecia, esgallándoa e opoñéndoa á do resto da Hispania céltica (1982: 265-6).

O marco xeográfico e cultural dentro do cal este autor defendía, en contraposición co exterior xentilicio, o predominio político dos castella, é a rexión que se corresponde arqueoloxicamente co castrexo e identificaba como «Gallaecia histórica» (1982: 266). Os castella, como sub-comunidades con territorio propio dependentes dun populus/civitas, desempeñarían con certa autonomía funcións políticas e administrativas en relación cun estatuto político independente ${ }^{45}$ que lles outorgaría a capacidade, entre outras, de estableceren pactos de hospitalidade (tábula do Caurel) e faceren, como comunidades, dedicacións a Xúpiter Óptimo Máximo

${ }^{43}$ Considerábase tamén significativo o feito de que todos os epígrafes con mención de $\supset$ correspondesen a individuos orixinarios das zonas mineiras do noroeste, xustificando así o interese romano por exercer maior control sobre eles. Esta idea, indefendible á luz dos datos epigráficos hoxe dispoñibles, xa fora abandonada polos seus defensores a pouco de comprobarse que o signo aparece representado en toda a área galaica; cf. Pereira, G., 1982: 250.

${ }^{44}$ Aquí non só non terían existido nunca as centurias, senón que ademais non hai o menor indicio dunha organización social xentilicia (Pereira, G., 1982: 265). Considerábaas de feito realidades excluíntes (1983).

${ }^{45} \mathrm{O}$ territorio do castro estaría incluído dentro do da civitas e ó existir un termo territorial para sinalar os limites entre o territorio da civitas e o do castellum, temos que supoñer para a comunidade do castellum unha certa independencia administrativa, que habería de traducirse necesariamente nunha independencia organizativa, cf. 1982: 255. 
(1983: 210). Por esta causa, os castella galaicos, que terían acadado un estadio organizativo máis próximo á respublica romana, teríalles parecido ós romanos máis asimilables e facilmente romanizables. Isto explicaría, paralelamente, que a partir da súa descomposición como sub-comunidades, chegasen a adquirir suficiente relevancia como para poderen expresar a origo por si mesmos e sen relación a unha entidade superior, especialmente por efecto da concesión do Ius Latii, posto que $s e$ antes non eran comunidades de verdade, agora $\mathrm{si}^{46}$.

A política romana de pactos, que pretendía a pacificación polo sometemento voluntario dos indíxenas, explicaría en moitos casos a posibilidade de supervivencia das súas formas de organización socio-política ${ }^{47} \mathrm{e}$ a conservación, e incluso florecemento, do patrón orixinario de asentamento, o castro, ata ben adiantado o s.I d.C. (1982a: 279, 284). A partir do derradeiro tercio dese século, como dixemos, o carácter destas comunidades cambiaría como consecuencia da concesión do Ius Latii: os castella perderían a súa autonomía política e deixarían de ser independentes en beneficio da constitución da civitas, realidade político-administrativa máis complexa tendente a integrar as comunidades en sistemas eficaces de control e goberno, con maxistrados e senado propios. En relación con este proceso de transformación teriamos que situar a cualificación da civitas como respublica, momento co que ademais coincidiría a definitiva baixada dos castros da poboación indíxena e a asignación a particulares de parcelas do solo público ${ }^{48}$.

Co novo estatuto os galaicos asimilarían o sistema romano, mais non para gozar das vantaxes da municipalización precisaban favorecer un incremento de asentamentos urbanos ${ }^{49}$. A inexistencia dun núcleo urbano que articulase as relacións

\footnotetext{
${ }^{46}$ A transformación do carácter das comunidades afectaría á referencia da origo dos individuos, como demostran o caso de Talabrigenses, para os orixinarios de Talabriga, ou Valabricenses para os de Valabrica. Se antes eran castella, agora semellan ser civitates, 1983: 206; 208, 210-1.

${ }^{47}$ Vimos que no primeiro achegamento de G. Pereira ó tema dos castella defendera, con J. Santos, a posibilidade dunha desmembración da sociedade xentilicia trala imposición dos cadros administrativos romanos (1980: 126); mais axiña deixaría de considerar ós castella como substitutos dunha realidade xentilicia para consideralos esquemas organizativos propiamente indíxenas reaproveitados polo poder romano (1983: 203-4). Pero novamente cambiaría de parecer ó afirmar que en contra da idea da pervivencia do indíxena, que tanto se ten utilizado e tanto se ten popularizado, debemos dicir que, dende os primeiros momentos posteriores á conquista, tivo lugar unha auténtica revolución nas comunidades prerromanas (1988: 252).

${ }^{48}$ Segundo este autor, o arrendo de parcelas de terra a particulares indíxenas teríase iniciado en época pre-flavia, posiblemente de maneira inmediata tralo remate da conquista; cf. Pereira, G. e Ferreira, C.A., 1981: 144; Dopico, D. e Pereira, G., 1993.

${ }^{49} \mathrm{Nin}$ a escaseza de municipios, colonias e centros urbanos, impedía supoñer para a Gallaecia unha completa transformación das súas comunidades por influencia romana; ver 1982a: 284.
} 
entre o agro e aquel, á maneira en que procedía o «bloque histórico» ${ }^{50}$, non impediría a estructuración do agro dende si mesmo no interior das comunidades galaicas, que poderían cubrir as funcións xudiciais, administrativas e de mercado a través de pequenos centros, como os fora mencionados nas fontes (Forum Limicorum, Bibalorum, Iriense, etc.) aínda que non representasen o elemento urbano do bipolar «bloque histórico» constituído pola cidade romana propiamente dita (1980: 29-30; 1982a: 286).

A nova realidade administrativa, que suporía, por outra parte, a formación dos conventus iuridici, redundaría novamente, segundo G. Pereira, na capacidade romana para distinguir entidades diferenciadas, desta vez no seo dunha mesma rexión. Neste sentido, o reparto dos pobos galaicos entre os dous conventos, Lucense e Bracaraugustano, non faría senón constatar a evidencia dunha heteroxeneidade de fenómenos culturais susceptibles de seren organizados mediante a creación de unidades administrativas ou xurisdiccións autónomas ${ }^{51}$. As diferencias entre brácaros e lucenses manifestaríanse tamén no rexistro arqueolóxico, nun xeralmente admitido atraso dos segundos con respecto ó relativo elevado nivel de desenvolvemento dos primeiros (1988: 252).

Unha vez asentados estes presupostos acerca da evolución dos castella galaicos, G. Pereira postulou para o momento da integración do noroeste no Imperio a creación ou inventio (co sentido de «encontrar»), a partir dunha realidade obxectivamente diferente, dunha rexión histórica por parte dos romanos ${ }^{52}$. A conciencia dunha

${ }^{50}$ 1982a: 286. Sobre a definición deste concepto tomado de Gramsci, a «relación dialéctica» entre o campo e a urbe unidos no «bloque histórico» que dá lugar á formación da cidade, ver Pereira, G., 1980: 25 ss.

${ }^{51} \mathrm{O}$ primeiro intento do Imperio por reorganizar territorial e politicamente as vellas comunidades indíxenas produciríase cedo no noroeste ibérico, a partir da creación do Conventus Arae Augustae, documentado na chamada Tabula Lougeiorum datada no primeiro ano da era (ver apén. epi. II. $\mathrm{n}^{\circ}$ 1). Para unha mellor comprensión deste fenómeno remitía ó artigo de Dopico, D., 1986, onde se defendía que a creación de conventus tan cedo na Península estaría en relación coa necesidade do Imperio de crear estructuras administrativas descentralizadas que permitisen unha rápida romanización nas zonas máis afastadas dos centros de poder, neste caso da capital provincial tarraconense. A concentración dos poderes xurídicos no ámbito conventual, xunto ó culto imperial tamén presente a este nivel administrativo, confirmarían a intencionalidade do Imperio de favorecer a rápida organización e integración duns territorios aínda recentemente conquistados (Pereira, G., 1988: 252).

${ }^{52}$ Un primeiro bosquexo desta teoría da inventio da Gallaecia preséntase en 1982a: Non quero dicir que os romanos inventasen os vínculos e características que facian de toda esta rexión algo diferenciado [...] pero non é menos certo que os romanos estaban forzando a todos estes pobos a ser conscientes da súa identidade. Esta idea sería máis tarde desenvolvida en 1988: 250 ss., ampliada en 1992, e exposta en estilo divulgativo en 1997. 
identidade cultural xenuinamente galaica adquiriría a súa primeira expresión na reforma dos límites provinciais practicada por Augusto, momento no cal a Gallaecia foi esgallada da Lusitania e incorporada na Citerior Tarraconense (1988). Pero, independentemente de que os galaicos tivesen conciencia ou non desa identidade, eles proporcionaban a «materia» (sub-comunidades constituídas en populi, é dicir, castella) sobre a que Roma había de impoñer a «estructura» (a civitas), sentando as bases para a consolidación dun sistema cultural e político unitario, preexistente, pero non necesariamente recoñecido polos seus membros con anterioridade ó proceso de formación da identidade galaica impulsado polo poder romano ${ }^{53}$. A «cultura castrexa», pouco precisa nos seus primeiros límites xeográficos, adquiriría a súa mellor expresión e máximo desenvolvemento a partir dese momento, cando a rexión propiamente galaico-romana se cingue ó territorio dos conventos lucense e bracaraugustano: creouse o concepto de Gallaecus, galego, a partir da experiencia de vivir na Gallaecia [...] teremos que concluír que estamos preto da constitución diso que chamamos «nacionalidade» no sentido de pertencer a un mesmo pobo, a unha nación (1992: 29).

A solidez da argumentación creba, sen embargo, ante a realidade descuberta polo autor de que os castella tamén están presentes fóra de Gallaecia ${ }^{54}$, cando Le Roux e Tranoy advertiran había xa máis de unha década da non coincidencia entre as áreas de dispersión do uso epigráfico do $\supset$ e máis dos castella ${ }^{55}$.

Situándose de partida na corrente de opinión iniciada por G. Pereira, $\mathrm{M}^{\mathrm{a}} \mathrm{Cruz}$ Gonzále $z^{56}$ realizaría un importante traballo de compilación das fontes epigráficas peninsulares de contido indíxena no que atopamos semellantes conclusións para as comunidades galaicas (especialmente 1986). Co fin de delimitar distintas áreas de xentilidades no marco da Hispania indoeuropea, esta autora estudiou

${ }^{53}$ Coas súas transformacións, os romanos criaron unha rexión histórica, a partir dunha base cultural común que, se cadra, só hoxe podemos valorizar en toda a súa importancia, e que talvez non era coñecida por aqueles indíxenas. Ou talvez si, mais non tiña vixencia naquel mundo tan primitivo, desintegrado. Así, os romanos non inventaron a nova rexión histórica a partir de nada. A materia existía xa, mais a estructura non. Nen tampouco a consciencia (1992: 31).

${ }^{54}$ A recente aparición da Tabula Lougeiorum rompe a absoluta diferenciación de Callaecia na súa forma de organización sociopolítica: os Lougei castellani toletenses da Táboa do Caurel [...] sabemos agora que eran ástures (1992a: 38, n. 8).

${ }_{55}$ Tranoy, A e Le Roux, P., 1984: 252. Sobre o particular xa se pronunciara tamén Alarcâo, J., 1988: 84, e viñan insistir máis recentemente Mangas, J. e Olano, M., 1995: 346. Sen embargo, isto non impediría que A. Tranoy (1993: 28) decidise finalmente renunciar ó seu posicionamento e adherirse á lectura contraria.

${ }^{56}$ Partindo das conclusións deste autor, consideraría o tema, ademais, definitivamente pechado; cf. 1985: 553 
sistematicamente todos os usos formulísticos epigráficos, tipo de onomástica, filiación, xentilicios, áreas de dispersión e relacións entre todos estes fenómenos, e como resultado das súas pescudas inferiu que a variedade rexional das expresións epigráficas debía corresponder a unha heteroxeneidade dos sistemas sociais entre os distintos grupos de poboación estudiados. As peculiaridades observadas levaron a establecer diferencias fundamentais, por exemplo, entre as comunidades que se acompañan de (ex) gente con respecto ás que o fan de gentilitas e, pola súa parte, coas que se expresan mediante xenitivos de plural $(1986 ; 1988)$.

Inclinábase a pensar, por outra parte, que serían razóns de orde puramente histórica, de graos de desenvolvemento no proceso evolutivo das unidades organizativas indíxenas, as responsables da diversidade social que se manifesta nesa variedade epigráfica. A estas causas habería que engadir tamén o efecto que sobre as representacións sociais terían determinadas prácticas económicas, xunto a outros condicionamentos derivados das sucesivas migracións de pobos, etc. (1986: 107 ss.). Na medida en que a combinación destes factores se concreta nunha diversidade de modelos sociolóxicos no seo mesmo da área das gentilitates, sería de esperar que a diferencia se acentuase con respecto á rexión noroeste, sobre todo se atendemos, como facía esta autora, á distribución étnica proposta por A. Tovar (loc.cit., a que vimos retomara $\mathrm{M}^{\mathrm{a}} \mathrm{L}$. Albertos). Pero, como veremos, a análise comparativa dos datos que se contrastan para confirmar esta hipótese non engade nada novo ás conclusións que J. Santos e G. Pereira sacaran dende a súa interpretación das comunidades galaicas (1986: 93-5):

- As inscricións con mención de $\supset$ non superan a fin do s.I d.C., mentres que as xentilidades acadan o s. III e aínda o IV.

- Os $\supset$ non sempre refiren a origo persoal, podendo facer dedicacións votivas (apén. epi I n ${ }^{\circ} 6$ e 20), como os populi, vici e pagi; nin as gentes, gentilitates, nin os grupos expresados mediante xenitivos de plural fan dedicacións a divindades.

- Os castella teñen territorio propio, non así os grupos xentilicios

- O signo $\supset$ pode ir acompañado de domo, que precisa aínda máis a origo das persoas: $D$ (omo) $\supset$ Acrip(a). Isto nunca acontece entre as gentes que, $o$ careceren de connotacións territoriais, obrígaas a precisar a origo mediante vicus.

De modo xeral, as conclusións sacadas da confrontación dos datos epigráficos para ambas as áreas, remiten ás mencionadas diferencias étnicas e de grao de desenvolvemento das distintas comunidades. Dende esta perspectiva, os Cántabros 
e Ástures permanecerían estancados nos vellos esquemas xentilicios debido á súa marxinalidade xeográfica, mentres que os Celtíberos, máis recentemente asentados na Península, serían portadores de formas máis complexas e evolucionadas e por iso facilmente asimilables polo sistema da civitas romana ${ }^{57}$. A Gallaecia, excluída da zona céltica, posuiría un sistema absolutamente diferente dos anteriores pero igualmente fácil de asimilar debido ó carácter político-territorial propio das súas comunidades, os castella.

Posteriormente a todos estes traballos comentados aparecería un artigo de F. Beltrán Lloris (1988) dirixido a resolver moitas das confusións terminolóxicas e conceptuais a que daba lugar a propia indefinición sociolóxica e histórica das sociedades prerromanas da Hispania indoeuropea.

A cuestión de fondo que F. Beltrán intentaba desentrañar radicaba nun problema historiográfico fundamental, xa denunciado con anterioridade por outros investigadores pero a penas tratado en detalle entre os estudiosos da Hispania antiga. O problema en cuestión referíase ó lastre que a historiografía moderna viña arrastrando con respecto ás primeiras teorías antropolóxicas formuladas no século XIX acerca das «sociedades xentilicias». Sinalaba, en primeiro lugar, a inconveniencia de empregar esta categoría, baseada nas extrapolacións feitas por L.H. Morgan das sociedades etnográficas contemporáneas sobre a gens e o genos da antigüidade clásica, posto que aquel autor non só compararía sociedades absolutamente irreconciliables nos planos sociolóxico e cultural senón que, ademais, os grupos de parentesco, que supoñía articulando completamente a vida das sociedades primitivas, non terían funcionado en ningún momento da historia grega ou romana como estructuras básicas do ordenamento social, político e económico das comunidades, con anterioridade á formación da cidade antiga (1988: 201 ss.). Así, a gens, da que L.H. Morgan tomara o modelo e o adxectivo "xentilicio» para referir calquera sociedade primitiva no estadio de barbarie, nunca tería existido como base dunha organización social fundada no parentesco, senón formando parte e dependendo dunha organización máis complexa na que igualmente se integraban outras agrupacións de distinta natureza, e non necesariamente formadas por reagrupamentos consecutivos de unidades inferiores, como se supoñía da phyle e phratria gregas a partir dos géne, ou da curia e a tribu romanas a partir das gentes (1988: 201,214). Por iso rexeitaba a tendencia común dos historiadores a reconstruír,

\footnotetext{
${ }^{57} \mathrm{Na}$ área celtibérica a introducción do modelo político-administrativo romano non debeu significar un cambio substancial no seo da sociedade indíxena porque de feito as unidades organizativas indíxenas existian xa formando parte da civitas, con senatus documentado epigraficamente, etc (1986: 100).
} 
sobre a base dunha estructura piramidal e tripartita deste tipo, a organización das comunidades da Hispania indoeuropea, subdividindo os grupos étnicos superiores en tribos e clans, chámense gens e gentilitas, fracción e sub-fracción, etc. (1988: 219-20).

Por outra parte, recoñecía enteiramente a dimensión territorial de todas estas comunidades, pero sen deixar de destacar a evidencia particular deste feito no noroeste, polas referencias epigráficas ós castella (é dicir, $\supset$ ). Polo demais, nada novo engadiría a este respecto, compartindo sen discusión todos os argumentos esgrimidos por G. Pereira na defensa da lectura que vimos presentando. Consideraba conveniente aceptar definitivamente a interpretación do $\supset$ como castellum, co cal o papel do parentesco suprafamiliar no noroeste quedaria reducido a un papel mínimo, e cando consideraba a mención epigráfica a unha unidade familiar como a interpretada por Coelho da Silva como familia extensa (cf. Coroneri Camali Domus...) e concedía ás comunidades cántabras, ástures, celtibéricas, vettonas e carpetanas (as expresadas epigraficamente mediante gentes, gentilitates e xenitivos de plural) certa natureza familiar ou parental, insistía na necesidade de desvincular este carácter dos esquemas morganianos para considerar a importancia complementaria doutros factores, territoriais, políticos, relixiosos, económicos ou bélicos, na base da constitución desas comunidades indíxenas (1988: 236-7).

Mais as críticas de F. Beltrán non só se dirixían á teoría xentilicia morganiana e á consideración do resto das sociedades indoeuropeas, celtas, xermanas, etc, como tales $^{58}$, senón que ademais rexeitaba toda posibilidade de comparanza coas sociedades cualificadas xenericamente polos antropólogos como «tribais». Segundo el, todas as evidencias que posuímos indican que os indoeuropeos peninsulares non chegaran a adquirir un grao de desenvolvemento semellante ó das cidades-estado do mundo clásico, pero si un nivel de adianto e sofisticación moi superior ó da maioría das tribais (1988: 203). A expresión «organización xentilicia» tería sentido, se acaso, na designación da sociedade primitiva romana, na que a gens xogaba un papel relevante, pero demostrada a súa impropiedade fóra deste ámbito, a proposta terminolóxica de Beltrán para definir as comunidades hispanas prerromanas é a de «organizacións suprafamiliares», ou outras [fórmulas] semellantes, máis neutras, dadas as dificultades para definir a natureza

${ }^{58}$ Non hai indicio ningún de que existise unha «organización xentilicia» na que a estructuración social, a producción económica, a mediación relixiosa ou a articulación política repousasen de maneira exclusiva ou principal sobre grupos de parentesco real ou ficticio, alomenos no mundo clásico greco-romano, itálico, celta e xermano no período considerado; en cambio os vínculos territoriais, políticos ou étnicos xogan un papel de primeira orde (1988: 218). 
dos grupos denominados nas inscricións gens ou gentilitas e a da sociedade en que actuaban (1988: 219).

En definitiva, non habería lugar na reflexión histórica para as xentilidades en sentido clásico, pero tampouco para un achegamento á organización daquelas sociedades dende un enfoque antropolóxico. Só un cúmulo de factores territoriais, políticos, relixiosos, económicos ou bélicos ós que non se conseguía dar forma nin definición porque a crenza na singularidade das comunidades hispanas, e particularmente das galaicas, non permitía establecer correlacións históricas ou culturais de ningunha clase. Unha aproximación ó carácter destas sociedades só parecía posible dende unha lectura intraducible das fontes epigráficas: castella na Gallaecia e grupos de carácter familiar no resto da Hispania indoeuropea (gentes, gentilitates e xenitivos de plural), de todo o cal extráese a única conclusión de que a diversidade das designacións reflicten unha heteroxeneidade social e cultural de feito entre as mesmas comunidades.

Sen embargo, e aínda aceptándose en xeral a lectura do signo como castellum, estamos aínda lonxe de acadar unha completa unanimidade respecto das súas implicacións. Así, J. Mangas considera que nalgunha das nosas inscricións (apén. epi. I $\mathrm{n}^{\circ} 20$ e II $\mathrm{n}^{\circ} 2$ ) o signo puidera tamén interpretarse como castellani, é dicir, como grupo social axente de diferentes accións, non necesariamente identificable coa poboación dun só castro, que posuiría unha posición relativa dentro da gens e capacidades xurídicas equivalentes ás da gentilitas. Disto conclúe que non debería abandonarse de todo a existencia de relacións xentilicias na area dos castella, ós que ó mesmo tempo considera entidades romanas que aproveitarían, con probabilidade, realidades indíxenas anteriores (Mangas, J. e Olano, M., 1995: 3434; Mangas, J. en Sánchez Palencia, J. e Mangas, J., 2000: 50-2, 60).

A recente descuberta do Edicto do Bierzo, que había servir a J. Mangas para confirmar estas sospeitas, permitiría a outros autores defender a creación ex novo dos castella en época romana co obxecto de consolidar, e incluso crear, estructuras de desigualdade social a partir das cales o Imperio dispuxese de elementos afectos e intermediarios co resto da poboación nativa. En efecto, tal e como se desprende do mencionado documento (datado no ano 15 a.C.), uns castellani Paemeiobrigensis da gens ástur dos Susarros, terían sido beneficiados por Augusto coa inmunidade perpetua e a posesión dos seus agros por teren permanecido fieis ó Imperio fronte a unha deslealdade que se suxire case xeneralizada. A partir deste dato, A. Orejas, I. Sastre, J. Sánchez Palencia e D. Plácido defenden que os castella ástur-galaicos non serían máis que comunidades rurais de pequenas dimensións integradas nunha civitas, sen connotacións administrativas, aínda que, visto o expresado no Edicto do ano 15 , se lles recoñecese os seus propios terreos de cultivo e unha certa au- 
tonomía organizativa (en Sánchez Palencia, J. e Mangas, J., 2000: 78). De calquera maneira, posto que estes autores non aceptan a existencia en época prerromana de organizacións supra-locais (entidades políticas ou territoriais superiores ó castro, Orejas et al., ob. cit.: 80 ), o significado do $\supset$, asimilable a castellum, non podería confundirse co «castro» prerromano. A xustificación deste feito deriva da propia consideración desta autonomía como privilexio reservado a unhas cantas comunidades, a través das cales o Imperio Romano crearía as estructuras de estratificación social necesarias para o bo funcionamento das redes de explotación imperial e canalización de recursos e máis para a consolidación das propias civitates: A posta en funcionamento do sistema de civitates implicou, por tanto, a total alteración das formacións sociais castrexas e a aplicación de novas relacións de desigualdade entre comunidades. A comunidade á que Roma chamou castellum puido coincidir cun castro prerromano, pero tamén pode identificarse cun asentamento doutro tipo, ou incluso, cun grupo deles (ob. cit.: 82).

Afondando nestes argumentos, I. Sastre (2001: 195) sería máis explícita. Segundo esta autora, o signo $\supset$ non podería facer referencia a calquera castro, posto que posúe connotacións que superan o simple contido toponímico, senón ós grandes oppida ou a núcleos centrais, non necesariamente de tipo castrexo, consolidados trala conquista e co que se pode identificar a aristocracia dominante. Polo demais, I. Sastre reacciona contra a hipótese tradicional castellanista que afirma o contido territorial e non social dos «grupos con $\supset$ », ata o punto de non desprezar a súa transcrición nin como gentilitas, nin como conventus ou conviventes (2001: $\left.196-8^{59}\right)$. Trátase, xa que logo, de dotar de contido social á realidade expresada polo signo.

Con esta nova proposta, posiblemente a máis fundada de cantas interpretan o signo como castellum, chegamos ó último chanzo desta liña interpretativa de corte histórico-institucional.

Pero outra relativamente nova solución había ser proposta partindo dun modelo de cariz histórico comparativo. $O$ interesante desta achega está en presentar a posibilidade de que a denominación das comunidades galaicas tivese sido obxecto dunha «traducción» semellante á que afectou ás gentes do resto da Hispania céltica. A nova proposta, a penas suxerida hai pouco máis de dúas décadas por P. Sáez Fernández (1978), recondúcenos outra volta á lectura de A. Schulten, pero afirmando en maior medida a tese sostida no seu momento por J.C. Bermejo.

\footnotetext{
${ }^{59}$ A falta de concordancia apuntada máis arriba entre os demostrativos hoc e eodem $\supset$ con substantivos non neutros, é desprezada por I.Sastre ó constatar que tamén o signo acompaña ó feminino domus en apén. epi. I, $\mathrm{n}^{\circ} 27$.
} 


\section{DE VOLTA ÁS CENTURIAS}

Facéndose eco da relación establecida por Rodríguez Adrados (1948: 137 ss) entre $\mathrm{o} \supset$ galaico e as centurias béticas documentadas en dous epígrafes do val do Guadalquivir (apén. epi. III), P. Sáez suxerira a posibilidade de que en ambos os casos se estivesen reflectindo residuos, en época imperial ${ }^{60}$, de antigas estructuras xentilicias prerromanas en diferentes poboacións célticas hispanas. Esta proposta baseábase no feito de que en ningunha outra parte do Imperio se coñece a existencia de entidades chamadas centuriae, que refiran unha circunscrición territorial e actúen como unidades de poboación. Esta circunstancia, que se deixa entrever nos mencionados documentos, onde se ven estas centurias participando en dedicacións conxuntas a un mesmo patrón ou divindade, impide interpretalas en calquera dos sentidos convencionais que este termo adquire no mundo romano imperial (unidade militar, subdivisión do ager, ou unidade de medida agrícola en Hispania: cf. 1978: 258-9). Isto, unido ó feito de que as súas denominacións se distinguen polo que parecen ser referencias toponímicas, é o que, en definitiva, suxire unha caracterización das centurias béticas como diferentes comunidades locais, aínda que integradas politicamente nunha mesma civitas. Se tomamos como exemplo o epígrafe de CIL II 1064, isto significaría que as centurias Ores, Manes, Halos, Erques, Beres, Arvabores, Isines e Isurgut., e quizais outras non mencionadas no documento, dependían da cidade de Arva. Finalmente, algúns aspectos da hipótese defendida por P. Sáez, como é a orixe clánica destes grupos, ou a latinización da propia denominación centuria a partir dun termo prerromano, non resultan tan consistentes como a conclusión de que, con toda probabilidade, as centurias da Bética equivalían a pagi ou distritos rurais dependentes das respectivas civitates. (1978: 271).

Esta hipótese sería máis recentemente apoiada por G. Chic García (1999) con argumentos de certo peso. Este autor, por unha parte, descubre nun grafito cerámico, indicando a procedencia do contido da ánfora, un Actes que se corresponde cunha das centurias de Carmo (apén. epi. III, $\mathrm{n}^{\circ} 1$ ). E, por outra parte, menciona tamén un epígrafe procedente da próxima colonia de Astigi no que se constata a presencia dun pagus Singiliense, unha demarcación que, como as centurias, conserva o seu nome prerromano. Tomando en consideración estes datos, G. Chic opina que en Carmo poderían darse razóns de simple conservadorismo respecto a Astigi para que alí os distritos rurais conservasen a súa denominación antiga, tratándose, en

${ }^{60}$ As centurias béticas dátanse arredor do 140 d.C. (1978: 256). 
calquera caso, de unidades organizativas de época prerromana semellantes ás que nas Galias (actual Francia e norte de Italia) reciben o nome de pagus. Polo demais, mostra completo acordo con P. Sáez sobre a identidade entre as centurias da Bética e as $\supset$ galaicas, interpretando a súa supervivencia ata época tan avanzada (mediados do s.II d.C.) como consecuencia da tendencia romana a disolver nos pobos conquistados unicamente as súas comunidades políticas tipo civitas, pero nunca os seus pagi (1999: 176-7).

A posición destes dous autores sobre a identificación das centuriae béticas $\cos \supset$ galaicos tamén se apoia sobre unha suposta orixe étnica común. En efecto, a pertenza daquelas centuriae a poboacións célticas habitantes no val do Guadalquivir fora sostida por P. Sáez en base a dous datos dignos de consideración: por etimoloxías célticas poderíanse interpretar os nomes das centurias; e a este tipo de asentamentos rurais se referiría Estrabón (con fonte en Polibio) ó afirmar que, mentres os Turdetanos foran xa plenamente romanizados, os seus veciños célticos vivían aínda komedòn «en aldeas» (III 2,15; 1999: 263-5). Sería posible, en consecuencia, que estes grupos fosen semellantes ós pagi galo-británicos, os cantóns ou circunscricións territoriais nas que se dividía o populus, ó que aportaban as unidades do exército, e que, á súa vez, estaban constituídos por varios vici ou aldeas.

Téñase, en conta, por tanto, que a recuperación da lectura do $\supset$ como centuria non significa retomar ó mesmo tempo o contido atribuído por A. Schulten a dita institución, senón aproximadamente como a entendía J.C. Bermejo, é dicir, como unha institución indíxena semellante á que noutras sociedades célticas serviron de canle de intervención do Imperio sobre os seus sistemas orixinais, posto que estes mesmos xa estaban configurados para permitiren unha eficaz e cómoda recadación de tributos e leva de tropas.

Con esta última achega pódese dar por finalizada a presentación do estado actual da investigación sobre as comunidades castrexas a través das fontes epigráficas. Pero permítase de seguido facer uns breves comentarios ó mesmo tempo que recapitulamos.

Ó longo destas páxinas vimos cómo a hipótese explicativa mellor acollida nos medios investigadores ata o cambio de milenio, aproximadamente, afirmaba a constitución das comunidades galaicas en torno ós castros, entendidos como as unidades políticas básicas da sociedade debido ó seu carácter territorial. Esta hipótese explicativa sostíñase, sen embargo, sobre argumentos moi febles. Por exemplo, as supostas «capacidades xurídicas» recoñecidas polo Imperio ós castros en canto entidades político-territoriais (indicar a origo dos seus habitantes, ofrecer 
dedicacións votivas a Xúpiter Óptimo Máximo, pactar tratados de hospitalidade), ou no son dereitos recoñecidos ás aldeas ou no soamente a elas. Sobre o primeiro punto, P. López Barja sinalou acertadamente que o ius originis é un dereito ligado á cidadanía romana e do que en ningún caso gozan os peregrini, estatuto do cal participaban os habitantes castrexos galaicos no momento no que se consigna epigraficamente o c invertido nas nosas inscricións (s. I d.C.). Por tanto, dificilmente os castella indicarían a origo dos seus habitantes. No que afecta ás dedicacións a Xúpiter Óptimo Máximo, non se entende que se considere un privilexio das comunidades territoriais cando o corpus epigráfico está inzado de individuos cumprindo particularmente cos seus votos a esta divindade. Finalmente, non é preciso sinalar os documentos hispanos nos que se observa ós considerados «grupos de parentesco» (por tanto, supostamente non territoriais: gentes e gentilitates Zoelas, cognatio Magilancum) asinando pactos de hospitalidade en pleno período imperial (sobre as súas características, ver esp. Beltrán Lloris, 1994).

Polo demais, nin mención merece que as comunidades castrexas galaicas fosen durante tanto tempo consideradas tan próximas á cidade romana como as propias póleis celtibéricas, polo simple feito de non documentarse entre elas as chamadas gentilitates. Por non mencionar o contrasentido que supón defender esta lectura «pereiriana» ó tempo que se afirma, dende o estudio da cultura material, o igualitarismo social castrexo (véxase por exemplo Calo Lourido, F., 1993: 176-7).

En consecuencia, posto que a través da equivalencia $\supset=$ castellum non se pretende suxerir a simple indicación epigráfica do castro de orixe, senón a presencia dunha institución política con determinadas capacidades xurídicas, o edificio construído en torno a esa equivalencia necesitaba dunha boa reconstrucción.

Esta había vir da man de varios autores, que corrixirían moitas das debilidades da tradicional hipótese castellanista. Sen embargo, a nova perspectiva reduce o proceso de romanización do noroeste a un fenómeno de contacto cultural estrictamente unilateral, onde o intervencionismo romano afecta tan decididamente a todos os aspectos da vida das comunidades indíxenas, que se acaba baleirando de contido a autonomía e o respecto ó ius peregrini que, como estes mesmos autores destacan, o Imperio practicaba entre as comunidades peregrinas estipendiarias.

No outro extremo temos a lectura «xentilicia» do signo, menos recesiva na actualidade do que na pasada década, aínda que hoxe en día só sexa defendida abertamente por A. Rodríguez Colmenero (2000:37-8). Con respecto a ela só cabe dicir que non é preciso estar excesivamente ligado á teoría clásica xentilicia para sostermos que a sociedade castrexa non manifesta ningunha incompatibilidade aparente coa organización interna dos seus grupos socio-políticos en base a principios de tipo familiar ou parental. Neste terreo os galaicos tampouco non terían por 
qué seren unha excepción no marco das sociedades antigas «non políticas» (no sentido de desprovistas de pólis). Nesta categoría, como sabemos, inclúense a maioría dos pobos protohistóricos europeos, coñezan ou non a aldea fortificada en altura como modelo de asentamento.

Vimos, por último, cómo se ampliaba o panorama da investigación coa recuperación da antiga lectura do signo como «centuria». O interesante desta lectura é ofrecer a visión do nivel que, entre o populus e o vicus, puido ter servido a Roma para introducirse nas estructuras políticas nativas do castrexo como fixera no resto do occidente europeo. Disto despréndese, indirectamente, que a consideración do castellum como a unidade socio-política elemental dos galaicos nos sitúa nunha situación tan insólita como inverosímil, posto que nos presenta ó único pobo antigo coñecido no que as comunidades rurais consisten en aldeas autárquicas e autónomas nas que o único factor de integración socio-política son os vínculos de veciñanza. Polo demais, dado quen nin centuria, nin gentilitas, nin conventus, concordan en xénero cos demostrativos hoc e eodem que acompañan ó signo nalgunhas das nosas inscricións, nada parece impedir interpretalo en efecto como castellum, pero sempre que se entenda como a indicación dalgunha peculiaridade do castro que sinala -por exemplo, como centro territorial, ver Brañas, R., 1995: 227 ss; e 2000: 143 ss -. Polo demais, a diferencia desta hipótese respecto á sostida máis recentemente por I. Sastre, A. Orejas, J. Sánchez Palencia e D. Plácido só se sitúa -o que non é pouco- na consideración deses centros como entidades políticas prerromanas, e non de creación imperial ex novo.

Chegados a este punto, hai que dicir que a aqueloutrada afirmación de que o significado do $\supset$ se resolve na lectura castellum, está hoxe en día moi lonxe de confirmarse. Por unha banda porque, como vimos, os mesmos defensores desta lectura non se poñen de acordo sobre o seu contido institucional; e, por outra, porque tampouco non se dan razóns convincentes polas que debamos abandonar definitivamente a perspectiva xentilicia ou, se se quere, indixenista do tema. Non hai nin que dicir que esta falta de entendemento se debe, fundamentalmente, á diversidade de correntes historiográficas dende as que se aborda a cuestión, posto que, mentres os uns miran cara dentro, intentando comprender a sociedade castrexa dende si mesma, os outros procuran comprendela inseríndoa dentro da órbita histórico-cultural na que esa sociedade se encadraría. En calquera caso, posto que a conivencia dalgúns especialistas da arqueoloxía (e aínda da filoloxía) coa lectura tradicional se manifesta cando menos desconectada, cando non abertamente en contradicción con ela, só cabe esperar a abordaxe do problema da romanización do noroeste peninsular dende unha óptica decididamente multidisciplinar, pero coherente. 


\section{APÉNDICE EPIGRÁFICO}

I. INSCRICIÓNS CON MENCIÓN DE つ

1. Apil[us] Arqu[i f.] [---] $\supset$ ACRIP[ia] h.s.est. S. Martinho de Dume, Braga. CIL II 2433. Desaparecida.

2. Arquius Viriati f. $\supset$ ACRIPIA h.s.e. Melgaecus Pelisti monument(um) posu[it].

Avelar, Braga. Cadernos de Arqueologia II, 6/7: 210.

3. Bodocena Aravi f. $\supset$ AGUBRI an. XII h.s.e.

Belmonte de Miranda, Asturias. Boletín del Instituto de Estudios Asturianos 144: 695-700.

4. Tillegus Ambati f. Susarrus $\supset$ AIOBAIGIAECO.

O Caurel, Lugo (ver infra Pactos de Hospitalidade, $\mathrm{n}^{\circ} 2$ ).

5. Fuscus Severi f. Lim(icus) $\supset$ ARCUCE an. XXII h.s.e. s.t.t.l. p.f.c. curante Tauroc[.].

Cerdeira do Coa, Guarda. O Archeologo Português 28: 213.

6. I.O.M $\supset$ AVILIOBRIS pr(o) s(alute).

Cores, Malpica, A Coruña. Corpus de Inscricións Romanas de Galicia I, $\mathrm{n}^{\circ}$ 66.

7. Caeleo Cadroiolonis $\mathrm{f}$. Cilenus $\supset$ BERISAMO an. LX et Caesarus Caeleonis f. an. XV h.s.s.

Cícere, A Coruña. Corpus de Inscricións Romanas de Galicia I, nº 52.

8. Flaus Auledi $\mathrm{f}$. Cabarcus $\supset \mathbf{B E R I S O}$ an. XV h.s.e.

Ablaneda, Salas, Asturias. Diego Santos, 1959: ${ }^{\circ} 17$.

9. Fusca Coedi f. Celtica Superta(marica) $\supset[B]$ LANIOBRENSI Secoilia Coedi f. soror sua posuit ${ }^{61}$. Astorga. CIL II $2902=5667$.

10. Nicer Clutosi $\supset$ CAURIACA principis Albionum an. LXXV hic s.est ${ }^{62}$. Vegadeo, Asturias. Diego Santos, 1959: $\mathrm{n}^{\circ} 14$.

\footnotetext{
${ }^{61}$ Dáse como inseguro o $B$ inicial porque S.Ma GARCÍA asegura distinguir no seu lugar un $E$ (Conimbriga 36, p. 99).

${ }^{62}$ A lectura Cauriaca debémoslla a $\mathrm{M}^{\mathrm{a}} \mathrm{L}$. Albertos (1975: 32, $\left.\mathrm{n}^{\circ} 8\right)$, quen detecta un nexo $\mathrm{A}^{\wedge} \mathrm{U}^{\wedge} \mathrm{R}$ non sinalado na edición de Diegos Santos. A forma marcadamente redondeada do punto de unión de A e R contrasta claramene coa unión angulosa non anexada das letras AN de an[norum].
} 
11. [...Vec]ius Verobli f. princ[eps -- - ] Cit(eriore) $\supset$ CIRCINE an. LX [--]o Veci f. princeps Co[pororum? - - - ] h.s.sunt heredes sib[i et suis] f.c. Lugo. Inscriptions Romaines de la Province de Lugo, $\mathrm{n}^{\circ} 34$.

12. Fabia Eburi f. Lemava $\supset$ ERITAECO a. XL Virius Caessi f. Lemaus $\supset$ eodem an. VII hic s.s. Caessius. Astorga. Martínez, M., 1986: 196-7.

13. Martiali an. X [---] an. IIII(?) s(?) $t($ ? $) \supset$ LAEDIE[.]S[.] Cemelen(us) Silo fili(i)s(?). Lugo. Inscriptions Romaines de la Province de Lugo $\mathrm{n}^{\circ} 31$.

14. Albura Caturonis f. $\supset$ LETIOBRI ann. LXX h.s.e. Braga. Melanges de la Casa de Vélazquez IX: 193.

15. Festus Lovesi f. Interamicus exs $\supset$ LOUCIOCELO hic sepelitus est an. III. Cacabelos, León. CMLeón, p. 60.

16. Eburia Calueni f. Celtica Sup(ertamarica) $\supset$ LUBRI an. XXVI h.s.e. Andiñuela, León. Conimbriga 36: 95-101.

17. Apana Ambolli f. Celtica Supertam(arica) [つ] MIOBRI an. XXV h.s.e. Apanus fr(ater) f.c.

S. Pedro de Mera, Lugo. Actas VII Coloquio sobre Lenguas y Culturas Paleohispánicas: 608.

18. Reburrus Ari Seur[r]us $\supset$ NARELIA an. LXII.

Felgar, Bragança. Ephemeris Epigraphica VIII 126: 407.

19. D.M. Lucila Vitalis $\supset$ OLCA an. XI.

Vila, Rodeiro, Pontevedra. Corpus de Inscricións Romanas de Galicia II, $n^{\circ} 84$.

20. I.O.M $\supset$ QUELEDINI.

Castro de Montejos, Ponferrada, León. Mañanes Pérez, T., 1982: 115, $\mathrm{n}^{\circ}$ 110.

21. Louci[a] Maturi f. Caladuma $\supset$ SAQUA a. L h.s.e. f.c. Maxuminus s.t.t.l. Petisqueira, Chaves. CIL II 2487. Desaparecida.

22. Tridiae Modesti f. Seurra Transm(iniense) exs $\supset$ SERANTE an. XX u(xori) $\mathrm{f}($ ecit) Valerius.

Felgueiras, Moncorvo. O Archeologo Português 29: 159.

23. $\supset$ SERMACELES B.F.D.

Monforte, Chaves. CIL II 2494. Desaparecida.

24. Anceitus Vaccei $\mathrm{f}$. Limicus $\supset$ TALABRIG(a) an. XXII h.s.e. s.t.t.l. [F]lavus Aquilus Frat[er] sui et Talavius Cloutius Cloutai f. et Urtenius [..] Turdae (f.) et fratres eius [f]aciendum curaveru[nt] ob m(erita) eius.

El Repilado, Huelva. CILA n ${ }^{\circ} 24$. 
25. Camalus Borni f. hic situs est annor. XXX exs $\supset$ TARBU frater faciendu(m) curavit.

Pastoria, Chaves. CIL II 2485.

26. Aemiliano Flaco de hoc $\supset$ TUREOBRIGA L.Aelius Flaccus signifer leg(ionis) II Aug(ustae) curavit instruendum vivo volente et presente sacratissimo suo patre.

Nogueira de Montanha, Chaves. CIL II 2480. Desaparecida.

27. Popillius Hirsutus Flavi Vendieci f. Lanci $\supset$ domo VACOECI an. XXXII h.s.e.

Sta. María de Trives, Ourense. G. Pereira 1982: 251; Inscripciones Romanas de Galicia IV 119.

28. Bassus Medami f. Crov[i]us $\supset$ VERIO an. XXV h.s.e. s.t.t.l. Coria, Cáceres. CIL II 774.

29. Ex $\supset$ ULIAINCA Lavasus Mebdi ex $\supset$ FA[- - - ] an. LXX. Vila do Conde, Douro Litoral. Ephemeris Epigraphica VIII 110: 398.

\section{Inscricións de lectura insegura:}

30. P.Ploutius P. f. Gal. Reburrus Interam[nicus] ex $\supset \mathbf{G A}[---]$ an. XXI h.s.e. [fraterna]e pietatis opu[s sed]emque videtis [extrem] am quae Plotio [saeva] in morte fuit [tunc cum] fratris Vegeti [inde di]cavit cura sep[ulcr]um et pietate [sua] i[u]stum persolvit amorem.

Aroche, Huelva. Corpus de Inscripciones Latinas de Andalucia, Vol I: ${ }^{\circ}$ 6.

31. L.Cas(ius) Caen(icus) Tamac(anus) $\supset$ NEM[- - - d dec(urio) al(ae) I Gig(urrorum) comp(luribus) bel(lis) torq(uibus) [p]hal(eris) [bi]s donatus Iovi O.M. v.s.l.m.

Castrelo de Val, Ourense. Tranoy, A e Le Roux, P., 1975: 276.

32. Navia $\mathrm{D} \supset \mathbf{P P R}$.

El Bierzo. Tranoy, A e Le Roux, P.,1984: 248, $\mathrm{n}^{\circ} 36$.

33. Navia Ancetolu(s) Auri exs $\supset$ SES[MACA?] votum possit q.e.c.i.

Procedencia descoñecida. Inscripciones Romana de Galicia IV 83. Desaparecida

34. S.T.P. $\supset \operatorname{Int}($ er) Como(?) I(nter) C(?).

Enxames, Vilardevós, Ourense. Rodríguez Colmenero, A: 1993: $n^{\circ} 4$. 


\section{PaCtos de hospitalidade do nOROeste Peninsular}

1. Tabula Lougeiorum (1 d.C.):

C.Caesare Aug. f. L.Aemilio Paullo cos./ Ex Gente Asturum conventus Arae/ August(a)e/ Civitas Lougeiorum hospitium fecit cum/C.Asinio Gallo libereis postereisque eius/ eumque liberos posterosque eius sibi libereis/ postereisque suis patronum cooptarunt/ isque eos in fidem clientelamque suam suo/rumque recepit. Egerunt legati/ Silvanus Clouti/ Noppius Andami.

$<$ Pereira Menaut, G., 1985-86: 301>.

2. Edicto do Bierzo (15 a.C.)

Imp(erator) Caesar Divi fil(ius) Aug(ustus) Trib(unicia) Pot(estate)/ VIII $\{I\}$ et pro co(n)s(ule) dicit: / Castellanos Paemeiobrigenses ex/ gente Susarrorum, desciscentibus/ ceteris, permanisse in officio cog/novi ex omnibus legatis meis qui/ Transdurianae provinciae prae/fuerunt. Itaque eos universos im/ munitate perpetua dono quosq(ue)/ agros et quibus finibus possede/runt, Lucio Sestio Quirinale leg(ato)/ meo eam provinciam optinente $\{\mathrm{m}\} \mathrm{m}$,/ eos agros sine controversia possi/dere iubeo./

Castellanis Paemeiobrigensibus ex/ gente Susarrorum quibus ante ea/ immunitatem omnium rerum dede/ram, eorum logo restituo castellanos/ Aliobrigiacinos ex gente Gigurro/rum, volente ipsa civitate, eosque/ castellanos Aliobrigiaecinos om/ni munere fungi iubeo cum/ Susarris./ Actum Narbone Martio/ XVI et XV K(alendas) Martias. M(arco) Druso Li/bone (et) Lucio Calpurnio Pisone/ co(n)s(ulibus).

$<$ Sánchez Palencia, F.J. e Mangas, J. (coords), 2000: 19>.

3. Tabula de O Caurel (28 d.C.):

Apio Iunio Silano P.Silio/ Nerva cos./ Tillegus Ambati f. Susarrus/ É Aiobaigiaeco Hospitium/ fecit cum Lougeis Castellanis/ Toletensibus sibi uxori libe/ris posterisque suis eumq/ue uxorem liberosque eius/ in fidem clientelamque sua/m suorumque in perpetuo Cas/tellanei Toletensis receperunt/ egit Tillegus Ambati ipse/ mag. Latino Ari et Aio Temari.

$<$ Inscriptions Romaines de la Province de Lugo, $\mathrm{n}^{\circ}$ 55>.

4. Tábula de Astorga ou dos Zoelas (27 d.C.):

M.Licinio Crasso/ L.Calpurnio Pisone/ cos./ III K maias/ Hospitium gentilitas Desoncorum ex Gente/ Zoelarum/ et Gentilitas Tridiavorum ex Gente idem/ Zoelarum hospitium vetustum antiquom/ renovaverunt eique omnes alis alium 
in fi/dem clientelam suam suorumque libero/rum posterorumque receperunt egerunt/ Araus Ablecaeni et Turaius Clouti Docius Elaesi/ Magilo Clouti Bodecius Burrali Elaesus Clutami/ per Abienum Pentili magistratum Zoelarum/ actum Curunda.

Segunda parte (152 d.C.):

Glabrione et Homullo cos V idus Iulias/ idem Gentilitas Desoncorum et Gentilitas/ Tridiavorum in eandem clientelam eadem/ foedera receperunt ex Gente Avolgigorum/ Sempronium Perpetuum Orniacum et ex Gente/ Visaligorum Antonium Arquium et ex Gente/ Cabruagenigorum Flavium Frontonem Zoelas/ L.Domitius Silo et/ L.Flavius Severus/ Asturica. $<$ CIL II 2633 $>$.

\section{INSCRICIÓNS CON MENCIÓN DE CENTURIAS NA BÉTICA}

1. Cerer(i) Frugif(erae) sacr(um)/ colleg(ium) agrimensor(um) carnonens(ium) et centur(iae)/ Albores Volces Agstes Ligyes/ colleg. agrimensor. segobiens. et centur./ Badyes Cinens Bodnes Armores/ colleg. agrimensor. hienipens. et centur./ Lides Moeles Hybres Limes/ colleg. agrimensor. arvens. et centur./ Isurgutes Halos Arvabores Ores/ colleg. agrimensor. oduciens. et centur./ Galles Secus Elpes Hares/ colleg. agrimensor. muniguens. et centur. Daudes Aves Albodunes Erques/ colleg. agrimensor. axatian. et centur./ Isines Alebries Lestes Hybres/ colleg. agrimensor. obulculens. et centur./ Melges Verges Belges Tornes/ Civitat(es) octo ceteriq(ue) populi res public(ae) col(legia) centur(iae)/ a(ere) p(ublico) com $[\mathrm{m}] \mathrm{u}[\mathrm{n}$ (iter)] pro fru[g(um)]/ in[c(rementis)] p(osuerunt) lib(enter)/M(arcus) Ulpius M(arci) f(ilius) L(uci) n(epos) M(arci) pro(nepos) Quir(ina) Strabo/ IIIIvir aug(ur) pont(ifex) dedicavit/ d(ecreto) d(ecurionum)

$<$ CIL II 128. Carmo (Carmona) $>$.

2. Q(uinto) Fulvio Q(uinti)/ Fulvi Attiani f(ilio)/ Q(uinti) Fulvi Rustici n(epoti)/ Gal(eria) Carisiano/ patrono et/ pontifici ob me/rita centuriae Ores Manes/ Halos Erques/ Beres Arvabores/ Isines Isurgut/ in locum quem ordo M(unicipium) $\mathrm{M}$ (unicipii)/ $\mathrm{F}$ (lavii) A(rvensis) decrevit posuerunt $\mathrm{D}$ (ecreto) $\mathrm{D}$ (ecurionum).

$<C I L$ II 1064. Arva (Alcolea del Río) >. 


\section{BIBLIOGRAFÍA}

ALARCÂO, J., 1988: O dominio romano en Portugal. Publicaçôes Europa-América.

ALBERTOS FIRMAT, Ma L., 1966: La onomástica personal primitiva de Hispania Tarraconense y Bética. CSIC. Salamanca.

- 1975: «Organizaciones suprafamiliares en la Hispania antigua». Studia Archaeologica, 37. — 1977: «Perduraciones indígenas en la Galicia romana: los castros, las divinidades y las organizaciones gentilicias en la epigrafía». Actas do Coloquio Internacional sobre el Bimilenario de Lugo. 1977 (p. 17-27).

- 1985: «La onomástica personal indígena del Noroeste peninsular. Astures y galaicos». Actas do III Coloquio sobre Lenguas y Culturas Paleohispánicas. J.de Hoz (ed.) Salamanca (p. 255310).

- 1988: «Sobre los castella del Noroeste peninsular». Actas do I Congreso Peninsular de Historia Antigua. Pereira Menaut, G. (ed.). Santiago de Compostela. Vol.II (p. 191-5).

BELTRÁN LLORIS, F., 1988: «Un espejismo historiográfico. Las «organizaciones gentilicias» hispanas». Actas do I Congreso Peninsular de Historia Antigua. Pereira Menaut, G. (ed.). Santiago de Compostela. Vol.II (p. 197-237).

BELTRÁN, F., DE HOZ, J. e UNTERMANN, J., 1996: El tercer bronce de Botorrita (Contrebia Belaisca). Zaragoza.

BELTRÁN LLORIS, F., 1994: Parentesco y sociedad en la Hispania céltica (I a.e.-III d.e). Revisiones de Historia Antigua I Las estructuras sociales indigenas del Norte de la Península Ibérica. Vitoria-Gasteiz (p. 73-104).

BERMEJO BARRERA, J.C., 1978: La sociedad en la Galicia castreña. Santiago. - 1978-1980: «Variaciones sobre el tema de la centuria». Cuadernos de Estudios Gallegos. T. XXXI. Santiago (p. 95-116).

BRAÑAS ABAD, R., 1995: Indixenas e romanos na Galicia céltica. Santiago. - 2000: Deuses, Heroes e Lugares Sagrados na Cultura Castrexa. Santiago.

CALO LOURIDO, F., 1993: A cultura castrexa. Vigo.

CAPALVO, A., 1996: Celtiberia. Un estudio de fuentes literarias antiguas. Zaragoza.

CARO BAROJA, J., 1977: Los pueblos del Norte. San Sebastián. - 1977a: «Organización social de los pueblos del Norte de la Península Ibérica en la Antigüedad». Legio VII Gemina. León (p. 13-62).

CHIC GARCÍA, G., 1999: «Comunidades indígenas en el sur de la Península Ibérica: dos notas». Pueblos, Lenguas y Escrituras en la Hispania Prerromana. Actas do VII Coloquio sobre Lenguas y Culturas Paleohispánicas. Villar, F. e Beltrán F. (eds.), Salamanca (p. 173-82).

COELHO da SILVA, A., 1985: «Novos dados sobre a organizaçâo social castreja». Actas do III Coloquio sobre Lenguas y Culturas Paleohispanicas. J. de Hoz (ed.) Salamanca (p. 201-24).

- 1986: A cultura castreja no Noroeste de Portugal. Paços de Ferreira.

COLLINGWOOD, R.G. e WRIGHT, R.P., 1965: The Roman Inscriptions of Britain. Oxford.

DIEGO SANTOS, F., 1959: Epigrafia Romana de Asturias. Oviedo. 
DOPICO CAÍNZOS, D., 1986: «Los conventus iuridici». Origen, cronología y naturaleza histórica». Gerión 4 (p. 265-83).

DOPICO CAÍNZOS, D. e PEREIRA MENAUT, G., 1993: «La gran inscripción de Remeseiros (CIL II 2476). Sobre la forma jurídica de tenencia de la tierra entre los indígenas bajo dominio romano». II Congreso Peninsular de Historia Antigua, Coimbra (p. 633-41).

ÉTIENNE, R., FABRE, G., LE ROUX, P., TRANOY, A., 1976: «Les dimensions sociales de la romanisation dans la Péninsula Ibérique des origines à la fin de l'Empire». VI Congres International d'Etudes Classiques. (Madrid, 1974) Paris (p. 95-107).

FAUST, M., 1979: «Tradición lingüística y estructura social: el caso de las gentilidades». Actas do II Coloquio sobre Lenguas y Culturas Prerromanas. Salamanca (p. 435-52).

GONZÁLEZ RODRÍGUEZ, M.C., 1985: «La organización social indígena del área indoeuropea de la Península Ibérica en la Antigüedad. Estado de la cuestión y consideraciones previas». Symbolae Ludovico Mitxelena Septuagenario Oblatae. Vitoria. Vol. I (p. 547-56).

- 1986: Las unidades organizativas indigenas del área indoeuropea de Hispania. Veleia anexo $\mathrm{n}^{\mathrm{o}} 2$. Vitoria-Gasteiz.

- 1988: «Sobre el sistema onomástico indígena del área indoeuropea de Hispania» Actas do $I$ Congreso Peninsular de Historia Antigua. Pereira Menaut, G. (ed.). Santiago de Compostela. Vol. II (p. 263-69).

LÓPEZ BARJA, P., 1999: «El censo provincial, los populi y los castella de Gallaecia». Gallaecia 18 (p. 347-62).

MANGAS, J. e OLANO, M., 1995: «Nueva inscripción latina. Castella y castellani del área astur». Gerión 13 (p. 339-47).

MAÑANES PÉREZ, T., 1982: Epigrafia y numismática de Astorga romana y su entorno. Astorga.

MARTÍNEZ MARTÍNEZ, M., 1986: «Últimas inscripciones romanas de Astorga». Actas I Congreso Internacional Astorga Romana (p. 196-7).

MARTÍNEZ MERA, J., 2001: «Expedicións militares a Gallaecia na época republicana». Gallaecia 20 (p. 297-316).

PEREIRA MENAUT, G. e SANTOS YANGUAS, J., 1980: «Sobre la romanización del Noroeste de la Península Ibérica: las inscripciónes con mención del origo personal». I Seminário de Arqueologia III (p. 117-137).

PEREIRA MENAUT, G., 1978: «Caeleo Cadroilonis f. Cilenus $\supset$ Berisamo et al.: Centuria or catellum? A discussion». Hispania Antiqua VIII (p. 271-81).

- 1980: «Historical Landscape and structures. A reflection on the case of Roman Galicia» Boletín Auriense X (p. 25-32).

- 1982: «Los castella y las comunidades de Gallaecia». Zephyrus XXXIV-V (p. 249-67).

- 1982a: «La formación histórica de los pueblos del Norte de Hispania. El caso de Gallaecia como paradigma». Veleia I (p. 271-87).

- 1983: «Las comunidades galaico-romanas. Hábitat y sociedad en transformación». Estudos de cultura castrexa e de $H^{a}$ antiga de Galicia. G. Pereira Menaut (ed.). Santiago (p. 199-212).

- 1985-1986: «Nueva Tabula Patronatus del Noroeste de Hispania». Studia Paleohispanica. IV Congreso sobre Lenguas y Culturas Paleohispánicas. Gorrochategui, J. Melena, J.L. e Santos, J. (eds.). Veleia 2-3, Vitoria-Gasteiz, 1987 (p. 299-303). 
- 1988: «Cambios estructurales versus romanización convencional. La transformación del paisaje político en el Norte de Hispania». Estudios sobre la Tabula Siarensis. Anejos Archivo Espanol de Arqueología IX. Madrid (p. 245-59).

- 1991: Corpus de Inscricións Romanas de Galicia I, Provincia de A Coruña. Santiago.

- 1992: «As orixes da Galiza: fundamentos para o estudo do pensamento galego na Historia».

O pensamento galego na historia. Aproximación crítica. Univ.de Santiago de Compostela (p. 23-35).

- 1992a: «Aproximación crítica al estudio de etnogénesis: la experiencia de Callaecia». Paleoetnología de la Península Ibérica. Almagro-Gorbea, M. e Ruíz Zapatero, G. (eds.). Complutum 2-3, Madrid (p. 35-43).

- 1997: «Un pobo e unha natio moi particulares». O feito diferencial galego na Historia (p. 237-49).

PEREIRA MENAUT e FERREIRA DE ALMEIDA, 1981: "A grande inscrición de Penedo de Rameseiros, Vilar de Perdizes, Montealegre (CIL II 2476)». Arqueología IV (p. 142-5).

RODRÍGUEZ ADRADOS, F., 1948: El sistema gentilicio decimal de los indoeuropeos occidentales y los orígenes de Roma. Madrid.

RODRÍGUEZ COLMENERO, A., 1972: «Sobre los pueblos prerromanos del Sur de Galicia». Boletín Auriense II (p. 193-240).

- 1977: Galicia meridional romana. Bilbao.

- 1979: Augusto e Hispania. Conquista y organización del Norte peninsular. Bilbao Memorias de Historia Antigua IV (p. 97-109)

- 1988: «Nuevos termini territoriales entre unidades gentilicias galaico-romanas». Actas do $I$ Congreso Peninsular de Historia Antigua. Pereira Menaut, G. (ed.). Santiago de Compostela, 1988. Vol.II (p. 271-89).

- 1993: Corpus-catálogo de inscripciones rupestres de época romana del cuadrante Noroeste de la Península Ibérica. Anejo $n^{\circ} 1$ de Larouco. Sada.

— 2000: «El más antiguo documento (año 15 a.C.) hallado en el noroeste peninsular ibérico. Un edicto de Augusto, sobre tabula broncínea, enviado a Susarros y Gigurros desde Narbona, de viaje hacia Hispania». Cuadernos de Estudios Gallegos T. XLVII, fasc. 112 (p. 9-42).

RÜGER, K.B., 1972: «Gallisch-Germanische Kurien». Epigraphische Studien IX (p. 251-60).

SÁEZ FERNÁNDEZ, P., 1978: «Las centurias de la Bética». Habis 9 (p. 255-71).

SÁNCHEZ PALENCIA, F.J. e MANGAS, J. (coords), 2000: El edicto del Bierzo: Augusto y el Noroeste de Hispania. Fundación Las Médulas.

SANTOS YANGUAS, J., 1984: Comunidades indigenas y administración romana en el Noroeste hispánico. Universidad del País Vasco.

- 1994: «Comunidades indígenas y administración romana en el norte de la Península Ibérica». Revisiones de Historia Antigua I: Las estructuras sociales indigenas del Norte de la Península Ibérica. Vitoria-Gasteiz (p. 181-99).

SASTRE PRATS, I., 2001: Las formaciones sociales rurales de la Asturia romana. Madrid.

SCHULTEN, A., 1962: Los Cántabros y Astures y su guerra con Roma. Madrid [1943, 1a ed.].

TOVAR, A., 1949: Estudios sobre las primitivas lenguas hispánicas. Buenos Aires. 
TRANOY, A., 1981: «Romanisation et monde indigène dans la Galice antique: problèmes et perspectives». I Reunión Gallega de Estudios Clásicos. Santiago (p. 105-121).

- 1981a: La Galice romaine. Recherches sur le nord-ouest de la Péninsule Ibérique dans l'Antiquité. Diffusion de Boccard. Paris

- 1993: «Communautés indigènes et promotion juridique dans le nord-ouest ibérique». Ciudad y comunidad civica en Hispania (Siglos II y III d.C.). Madrid.

TRANOY, A. e LE ROUX, P., 1973: «Rome et les indigènes dans le Nord-ouest de la Péninsule Ibérique, Problèmes d'epigraphie et d'histoire». Melanges de la Casa de Velázquez IX (p. 177232).

- 1975: «Problemes epigraphiques de la province d'Orense». Boletín Auriense V (p. 271-9).

- 1984: «つ, le mot et le chose. Contribution au débat historiographique». Separata de Centro de Estudos Humanísticos. Porto (p. 239-55).

VILLANUEVA ACUÑA, M., 1984: «Sobre el problema del signo». Gallaecia 7/8 (p. 187-200).

VILLAR; F., 1995: Estudios de celtibérico y de toponimia prerromana. Ed. Universidad Salamanca. 